\title{
Müzik Sosyolojisi Bağlamında Tunceli'de Bağlama Çalgısının Yaygınlığı ve Toplumun İnanç Yapısıyla Olan İlişkisi
}

\author{
DOI: $10.26466 /$ opus. 841307
}

$*$

\author{
Tuncay Yildirım * \\ * Dr. Öğr. Üyesi, Munzur Üniversitesi, Güzel Sanatlar Tasarım ve Mimarlık Fakültesi, \\ Tunceli/Türkiye \\ E-Posta: tuncayyildirim@munzur.edu.tr \\ ORCID: $\quad$ 0000-0002-3963-9878 \\ Öz
}

Bu araştırmada, nüfusunun büyük bir kısmı Alevi inancına mensup bireylerden oluşan Tunceli'deki müzik ve toplum ilişkisi, Aleviler için taşıdığı inançsal imgelerden ötürü ayrıcalıklı bir çalgı olan ve Alevi müziğinin başlıca taşıyıcısı ve aktarıcısı olan bağlamanın toplumdaki yaygınlı̆̆ı ve konumu üzerinden ele alınmaktadır. Tunceli'deki Alevilerin ev ve aile ortamlarında bağlamanın yaygınlığı, bağlama çalan kişilerin toplumdaki artan azalan değerleri ve bu kişilerin bağlama ile Alevilik inancı arasında kurduklarn ilişki, nicel araştırma yöntemlerinden survey araştırma tekniği kullanılarak elde edilen verilerin analizleri üzerinden betimlenmektedir. Ayrıca Tunceli'de bağlamanın konumunu destekleyen kültürleme ve geleneğin muhafazası gibi kültürel süreçlere de kısaca değinilmektedir.

Araştırmada yaş ve cinsiyet farklllkklarn göz önünde bulundurularak tesadüfi örneklem ile rastgele seçilmiş yüz atmış beş kişiye, sosyolog ve istatistikçi öğretim üyelerinin yanı sıra biri bağlama eğitimi veren müzik öğretmeni ve halktan seçilmiş bir kişi ile hazırlanan yirmi altı soruluk bir anket uygulanmıştır. Anketlerden elde edilen nicel verilerin bilgisayar ortamında SPSS (Social Package for Social Science) programı ile frekans ölçümleri gerçekleştirilmiştir. Araştırmanın sonucunda, Tunceli'de bağlamanın diğer enstrümanlara göre daha yaygın olduğu, insanların bağlamayla inançları arasında yakın bir ilişki kurdukları, inanç öğelerinin kültürleme aracılı̆̆ıyla bă̆lamanın yaygınlığı ve muhafazasını desteklediği tespit edilmiştir.

Anahtar Kelimeler: Müzik ve Toplum, Müzik Sosyolojisi, Alevilik, Bağlama, Tunceli. 


\title{
The Prevalence of Bağlama in Tunceli in the Context of Music Sociology and Its Relationship with Society's Belief Structure
}

\begin{abstract}
In this study, a large part of its population consisting of individuals owning of the Alevi faith in Tunceli music and society relationship are discussed over location and prevalence in society the Baglama's transmitter and carrier main of Alevi music which is an instrument privileged because of the belief images he carries for Alevis. The Bağlama's of prevalence in environments home and family of Alevis in Tunceli, values decreasing and increasing of people who play in the bağlama and these people relationship establish between Baglama and Alevi faith, is described through analysis of the data obtained using survey research techniques. Also cultural processes such as preservation of tradition and acculturation position of the baglama in Tunceli is briefly mentioned over its prevalence in society of Bağlama.

In the study, by random sampling considering differences gender and ageselected randomly people hundred sixty five was applied a questionnaire twenty six questions prepared with a person chosen from the public and a music teacher who teaches baglama as well as faculty member statistician and sociologist. The quantitative data obtained were carried out frequency measurements in computer environment with SPSS (Social Package for Social Science) program. As a result of the research, in Tunceli of prevalence Bağlama acording to other instruments, people establish a close relationship between baglama and their beliefs, has been determined that the belief elements are supported by the extensiveness and preservation of the bağlama through acculturation.
\end{abstract}

Keywords: Music and Society, Music Sociology, Alevism, Bağlama, Tunceli. 


\section{Giriş}

Müzik ve toplum ilişkisine değinen birçok araştırmada (Ayas, 2015, s.55-69; Finkelstein, 1995, s.26-28; Erol, 2015, s.18; Say, 2001, s.219; Soykan, 2005, s.76) müzik, toplumu oluşturan temel özne olan insanın bir tasarımı olarak görülür ve böylelikle müzikle toplum arasındaki sosyolojik ilişki doğrudan basit bir indirgemeci yaklaşımla kendiliğinden kurulmuş olur. Çünkü bu yaklaşıma göre herhangi bir müzik eseri, tablo veya edebiyat yapıtı sadece estetik ve sanatsal biçimiyle insanlara tek başına olgusal bilgi vermek için yetersizdir. Eseri daha da anlamlı kılan ve onun insanlar üzerindeki etkisini arttıran şey, ancak eserin toplumsal olarak betimlediği imgeler anlaşıldığı zaman ortaya çıkarılabilir. Örneğin S. Finkelstein için (1995, s.26), "müzik, anlatacaklarını pek çok biçim aracılığıyla dile getirir. Bunlar halk şarkısı gibi yalın imgeler ve bir Brahms ya da bir Beethoven senfonisinin bir bölümü gibi derin iç çatışmaları ve çözülüşleri sunan karmaşık insan betimleri biçiminde olabilir." Ya da Beethoven'in Egmont Uvertürü veya Eroica'sı kahramanlık, çatışma, görkemli bir zafer kutlaması gibi derin bir insan betimini içerir ve ancak bunlarla düşünüldügünde daha da anlam kazanır. Kısacası "müzikte içinde olmak üzere, güzel sanatların hepsinde her insan betiminin toplumsal bir alg1 dayanağı bulunur... Müzikte "öykü" aramak, sonu olmayan bir uğraştır. Ama bir müzik yapıtını kendi toplumsal bağlamı içerisine yerleştirmek, böylece genel portresine tikel bir giysi giydirmek, o yapitı anlamanın tek yoludur" (Finkelstein, 1995, s.28). Hatta güzel sanatlar düşüncesi ve tarihinin dönemsel özelliklerini izah etmenin yolu uzun vadeli sosyolojik bir bakış benimsemek ve bu dönemi ortaçağın sonlarında başlayan bir toplumsal ayrışma sürecinin nihai evresi olarak görmektir (Shiner, 2001, s.124). Müzik ve toplum arasındaki ilişkiyi somutlaştırmayı kolaylaştıran bu basit indirgemeci yaklaşımın, müzik sosyolojisinin hareket noktasını oluşturduğu söylenebilir. Temelde müzik sosyolojisi de müzik ve insan ilişkisini anlamaya yönelen, toplumsal olanla müzik arasında anlam bütünlüğü kurmaya çalışan bir disiplindir. Müziğin seslerle oluşan soyut saf yapısını somutlaştırmak ve sahip olduğu özellikleri-farklılıkları açıklamak için sürekli toplumsal indirgemeler yapılır ve insanlar, kitleler veya toplumlar arasındaki müzikal farklılıklar, müziğin içerisinde üretildiği toplumsal bağlama indirgenerek açıklanır. Çünkü "müzik sosyolojisi, müziğin toplumdaki yerini ve etkilerini araştıran" bir bilim dalıdır (Günay, 2011, s.20). “Bir sanat dalı olarak müziğin toplumsal 
bileşenlerini; siyaset, din, ekonomi, kimlik, cinsiyet ve gündelik hayat pratikleri gibi alanları içerecek şekilde, parçalı ve dinamik örüntüleri incelemeyi hedeflemektedir." Bu sayede, müziğin içerisinde üretildiği toplumsal koşulları anlayabilmek ve toplumun içinde bulunduğu koşullar üzerinden müziğin konumu hakkında yorum yapmak ve çıkarımlarda bulunmak mümkün hale gelmektedir (Güven ve Ergur, 2014, s.2). Müzik ve toplum ilişkisini konu edinen araştırmaların müzik sosyolojisiyle olan yakın ilişkisi hakkında Ayas, meseleyi derin bir literatür taramasıyla örnekleyerek, Alan P. Merriam, Richard A. Peterson, P. J. Martin, E. Fischer, S. Finkelstein gibi isimlerin müziğin özellikleriyle içerisinde yaratıldığı toplumsal özellikler arasında yakın bir bağ olduğu görüşüne sahip olduklarını ve bu isimlerin müzik ve toplum ilişkisini açıkladıkları çalışmalarını müzik sosyolojisi başlığı altında değerlendirebilmenin mümkün olduğunu söylemektedir. Örneğin Alan P. Merriam'a göre, "müzik belli bir kültürü oluşturan toplumun ortak değer, tutum ve inanışları tarafından şekillenen insana özgü davranışsal süreçlerin bir sonucudur." Veya "Richard A. Peterson (2007, s.3128-3129) müzik sosyolojisinin beş temel yaklaşımından ilkinin farklı toplum tipleriyle farklı müzik tiplerini ilişkilendirme çabalarına dayandığını kaydeder" (Akt: Ayas, 2015, s.55). Ayas'ın kendisine göre de, müzik ve toplum ilişkisini basit bir denklemle anlayabilmek mümkündür. Hatta "tarihin farklı dönemlerinde, aynı toplumun farklı toplumsal katmanlarında ve dünyanın farklı toplumlarında birbirinden çok farklı müzik geleneklerinin hüküm sürmesi toplumla sanat arasında bariz bir ilişki olduğunu bize ilk bakışta söyleyen" basit denklemlerden bir tanesidir (Ayas, 2015, s.57-59). Ayrıca müzik, toplumsal kimliğin somutlaştığı güçlü bir duygusal deneyim sağladığı gibi kitlerde ortak bilinç oluşturmada da oldukça etkilidir. "Müziğin harekete geçirdiği ilişkiler bütün bir topluluğu kapsayabilir (Kaplan, 2013, s.14). Bu yüzden farklı özelliklere sahip olan toplumlarda müziğin konumu, geçirdiği değişim süreçleri veya toplum içerisindeki belirli müzik tarzları arasındaki farklılıkların nelerle alakalı olduğu araştırıldığında daima toplumsal olan öğelere insan, kitle, toplum özelinde indirgemeler yapmaya ihtiyaç duyulur. Bu durumun müzikoloji çalışmalarının birçoğu içinde geçerli olduğu söylenebilir. Mesela, tarihsel müzikoloji başlı̆̆ı altında yapılan çalışmaların birçoğu zorunlu olarak müzik ve toplum ilişkisini sorgulamaya ihtiyaç duyar. Çünkü "müzik tarihi; insan kültüründe müziğin varoluşundan günümüze kadar geçen sürede, müziğin doğuşunu, gelişi- 
mini, kazandığı başarıları, ilişki ve sorunları zaman ve mekan göstererek inceler" (Günay, 2011, s.36). Veya müzik felsefesiyle ilgilenen bir araştırmacı, zorunlu olarak toplumun düşünce yapısı veya toplumdaki düşünce akımlarına yönelir, bunlardan söz eder ve bunlarla müziğin ilişkisinin ne olduğunu sorgulamak durumunda kalır. Keza "müziğin toplumsal bir etkinlik olduğu ve müzik eserlerinin sadece düzenlenmiş seslerin bir birikimi olmadığı" görüşü Konfüçyus, Platon ve Aristoteles gibi düşünce dünyasının önde gelen isimleri tarafından da fark edilmiştir (Soykan, 2009, s.62). Dahası etnomüzikoloji çalışmaları, popüler kültür-müzik çalışmaları, ya da müzik psikolojisi gibi insan, birey, kitle merkezli yürütülen birçok başlıkta müzik ve toplum ilişkisi kendiliğinden zaten vardır (McGregor, 1983, s.21; Stokes, 1992, s.133179; Shiner, 2001: 21, 152-168; Ayas, 2015, s.53, 153; Güven ve Ergur, 2014, s.14). Dolayısıyla bu gibi çalışmalarda müzik sosyolojisinin varlığından söz etmek kendiliğinden meşrulaşmış olur. Bu açılardan düşünüldüğünde araştırmanın genel perspektifi ve odaklandığı noktaları temelde müzik ve toplum ilişkisi oluşturmasından ötürü, araştırmanın kendisinin doğrudan müzik sosyolojisi başlı̆̆ı altında değerlendirilebileceğini söylemek mümkün hale gelir. Çünkü bu araştırmayla anlaşılmaya çalışılan şey, Tunceli'de bağlamanın yayginlığıyla toplumun inanç yapısı arasında nasıl bir ilişki olduğudur. İnanç, insanların içinde bulundukları durumları algılama, tanıma ve bu durumların kendileri için ne anlama geldiğini belirginleştiren sosyolojik bir kavramdır. İnsanların çevreleri ile kendilerine ilişkin oluşturdukları bilgi ve düşüncelerin bir bölümü, içine doğdukları toplumun inanç yapısı sayesinde oluşur (Ozankaya,1982, s.333-334). Dolayısıyla Tunceli'de bağlamanın konumu ve insanların bu çalgıya yönelik olarak kazandıkları müzikal donanımlarla toplumun inanç yapısı arasında bir ilişki kurulabilir. Çünkü bağlama Alevilik inancının vazgeçilmez öğelerinden birisidir. Buradan hareketle Tunceli'deki müzik ve toplum ilişkinin yansımaları, Alevi inanç ritüellerinin en önemli unsurlarından birisi olan bağlama çalgısı özelinde ele alınmaktadır. İnanç yapısının bağlamanın Tunceli toplumdaki konumuna etkileri, insanlar için taşıdığı anlamlar ve inancın kültürleme aracilığıyla topluma kazandırdığı müzikal donanımlar, Alevi inanç sistemindeki yeri ile sıradan bir müzik aleti olmaktan çıkan bağlamanın, Tunceli toplumundaki yaygın kullanım oranları üzerinden tartısılmaktadır. Ayrıca bağlamanın Tunceli'deki konumu ve insanlara dolaylı olarak kazandırdığı müzikal donanımlar üzerinden, Tunceli toplumunun müzikle olan ilişkisi hakkında belirli oranlarda betimlemeler yapmakta 
mümkün hale gelebilir. Çünkü bir toplumdaki enstrüman çalan insanların sayıs1, ev, aile gibi ortamlarda her hangi bir enstrümanin bulundurma oranları, insanların aile bireylerinden en az birisinin enstrüman çalıyor olabilmesi veya ailelerin kültürel olarak kendilerinden sonraki kuşağa aktardığı bütün müzikal etkinliklerin, bir toplumdaki müzik toplum ilişkisinin anlaşılması için önemli bir veri tabanı oluşturması muhtemeldir. Bu yüzden bahsi geçen ayrıntılara bakılarak Tunceli'deki müzik ve toplum ilişkisi hakkında yapılacak olan karşılaştırmalı veya genelleyici bütün yorumların doğruluk payının olduğu söylenebilir. Aynı zamanda lokal olarak Tunceli'nin Alevi kültürüne mensup toplumlar için oluşturacağı örneklem, Alevi inanç kimliğine sahip toplumların müzikal donanım ve beceri seviyelerinin arka planının tartışılabilmesine de imkan sağlayacaktır. Çünkü Alevi insanların yoğun olarak bir arada yaşadığı Tunceli'nin Alevi inancına sahip toplumlar için oluşturacağı model, Alevi müziğinin arka planında yer alan kültürel aktarım süreçlerinin anlamlı bir göstergesi olacağından, müziğin dolaylı olarak bu toplumlarda ne gibi özelliklere sahip olduğu, inancın dolaylı yollarla insanları müzikal olarak nasıl kültürlediği, bu durumun insanların müzikal beceri ve donanımlarına ne derecede yansıdığı gibi kavramların genellemesini yapmak mümkün hale gelecektir.

\section{Tunceli'nin Demografik Özellikleri}

Tunceli, bulunduğu bölge ve sahip olduğu konum itibariyle geçmişte birçok uygarlığa ev sahipliği yapmış Sümer, Hitit, Asur Urartu, Med, Bizans, Selçuklu ve Osmanlı gibi birçok medeniyete ait izlerin yok olmadan günümüze kadar taşındığı bir şehirdir. Halk türkülerine konu olduğu gibi doğası itibari ile dört tarafı yüksek dağlarla çevrili, senenin belirli aylarında bol yağış alan, içerisinde büyük akarsuları barındıran bir arazi yapısına sahiptir. Tunceli, nüfusu ve nüfus yoğunluğu bakımından ülkedeki diğer illerle kıyasland1ğında son sıralarda yer alır. "Bunda coğrafya ve sosyo-ekonomik şartların etkisi vardır. Erkek nüfusu kadın nüfusundan daha fazladır. Tunceli ili, 31,9 ortalama yaş ile ülke genelinden ve içerisinde yer aldığı bölgeden daha yaşlı bir nüfusa sahiptir" (Solak, 2016, s.6). Bugün şehirde yaşayan insanların büyük bir kısmını başta yerel halk olmakla birlikte her hangi bir kamu kurumunda çalışan kişiler ve üniversite öğrencileri oluşturmaktadır. "2012 yılı 
Adrese Dayalı Nüfus Kayıt Sayımı sonuçlarına göre toplam 85.062 kişilik nüfusa sahip olan Tunceli, $7.774 \mathrm{~km} 2$ yüzölçümü ile Türkiye topraklarının yüzde birini kaplamaktadır" (Parlayan, 2012, s.4). Tunceli, ayrıca temel eğitimden orta öğretime geçiş sınavlarında önemli başarılara sahip olmasıyla kamuoyunda adından sıkça söz ettirdiği gibi, toplumda okuma yazma oranının Türkiye'deki diğer illere göre dağılımının en ön sıralarında yer almaktadır. Demir, Tunceli'nin eğitim seviyesindeki yüksekliği, temel eğitimden orta öğretime geçiş sınavlardaki başarısından hareketle şöyle açıklamaktadır: Tunceli, "son üç yıldır liselere yerleştirme için kullanılan Temel Eğitimden Ortaöğretime Geçiş (TEOG) sınavlarında Türkiye birincisi olmuş bir ildir. İl ayrıca, Türkiye İstatistik Kurumu'nun (TUIKK 2016) illerde Yaşam Endeksi Araştırması'na göre de eğitimde en başarılı ildir" (Demir, 2019, s. V). Tunceli üzerine sosyolojik bir analiz araştırmasının editörlüğünü yürüten Solak ise (2016: 8), "temel eğitimden orta öğretime geçiş sürecinde uygulanan SBS ve TEOG sınavlarının sonuçları açısından bakıldığında" Tunceli'nin 2011-2016 yılları arasında ülke geneline göre önemli bir artış gösterdiğini ifade etmektedir. Her iki yazarın açıklamalarına bakıldığında 2011-2019 yıllarını kapsayan süreçte Tunceli'nin eğitim seviyesi bakımından ülke ortalamasının üzerinde bir tablo sergilediği anlaşılmaktadır. Alevilik hakkında önemli araştırmalar yapmış olan Cemal Şener, Tunceli'nin inanç yapısını Aleviliğin ibadet biçimi olan Cem ritüelleri ile birlikte değerlendirir ve bu yörede Cemlerde okunan gülbank ve nefeslerin Türkçe okunduğunu, bu konuda araştırmalar yapmış olan Bruınessen'a atıf yaparak açıklar (2002, s.2).

\section{Alevilik İnancının Tunceli'de Bağlama Çalgısının Konumuna Etkileri}

Kültürel özellikleri bakımından zengin bir mirasa sahip olan Tunceli, inanç değerleri bakımından Alevi inanç kimliğine sahip kişilerin yoğun olarak yaşadığı bir yerdir. Halkın "yüzde doksanı Alevidir." Tunceli'de Aleviliğin inanç temellerini yansıtan "ocakçllık, ziyaretçilik" gibi kavramlar insanlar tarafından yaygın olarak yaşatılmakla birlikte, güneş doğarken salavat getirme veya ay doğarken dua etme gibi doğa inanışları da Tunceli Aleviliği inanç değerlerinin bir parçasıdır (Kaya, 2004, s.120, 143). Tunceli (Dersim) inanç sistemi Alevilik inanç ve pratiklerini içeren, ocak ve soylara bağlanan ata kültü ve doğa inanışlarını yansıtan üçlü bir yapıya sahiptir (Deniz, 2012, s.52). Ayrıca Tunceli' de Türkçe'nin yanı sıra Kurmanci, Zazaca, Dersimce, Dimiliki, 
Herewere, So-be gibi birbirinden farklı yerel dillerin konuşulduğu da bilinmektedir (Kaya. 2004, s.279, 285; Gültekin, 2007, s.55). Hâlihazırda konuşulmaya devam eden bu diller geçmişten günümüze Tunceli'de okunan türkü ve ağıt repertuvarında oldukça önemli rol oynamaktadır (Düzgün, 1992).

Tunceli'deki Alevilerin ibadet biçimi olan Cem ritüellerinin, müzik ve bağlama eşliğinde gerçekleştirilmesi, bağlamayı insanların yaşantısında önemli bir yere koyar. Ayrıca Cemler, bağlamanın kültürel aktarımının sürekliliğini sağlayan kültürel süreçlerin oluşmasına da önemli ölçüde katkı sağlar. Hızır Cemi, Muharrem Cemi, Görgü Cemi, Musahiplik Cemi, Kırklar Cemi vs. birbirinden farklı amaçları ve uygulamaları olan Cem ritüellerinin hepsinde müzik ve bağlama inançla iç içe geçmiş girift bir yapı halindedir. Bazı bölgelerde Muharrem ayı "yas-1 matem ayı" olması nedeniyle, Muharrem Cem'lerinde semah dönülmediği bilinmektedir. Fakat Tunceli' de katılım gerçekleştirdiğimiz Muharrem Cem'lerinde, Alevi dedesi veya zakir tarafından bağlama ile seslendirilen semah müzikleri eşliğinde, semah ritüelinin gerçekleştirildiği gözlemlenmiştir.

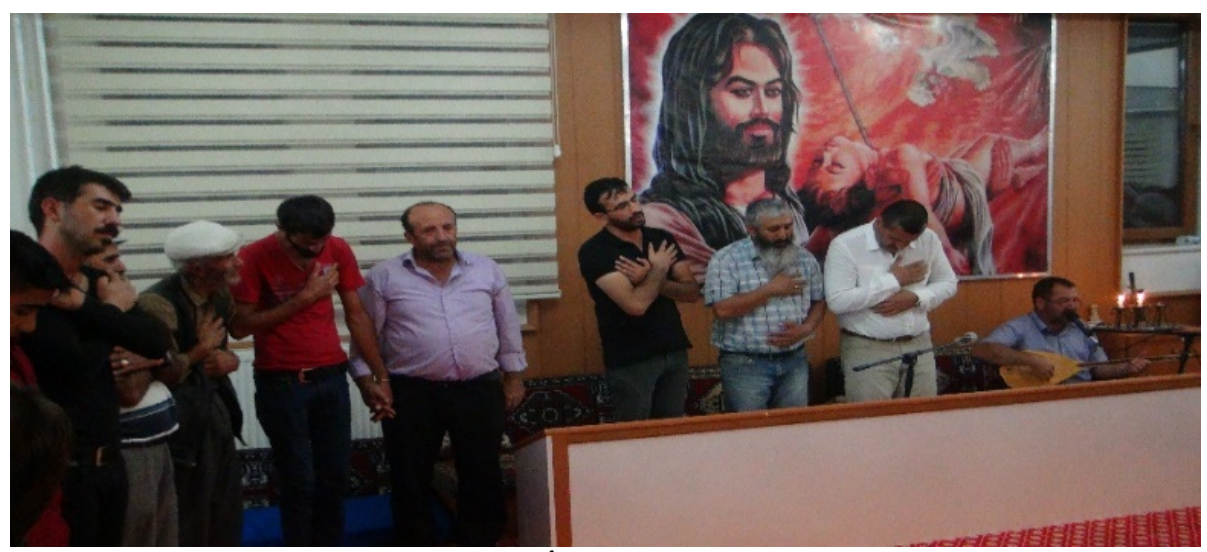

Şekil 1. Tunceli Merkez İlçe Muharrem Cem'i Görseli (2018). 


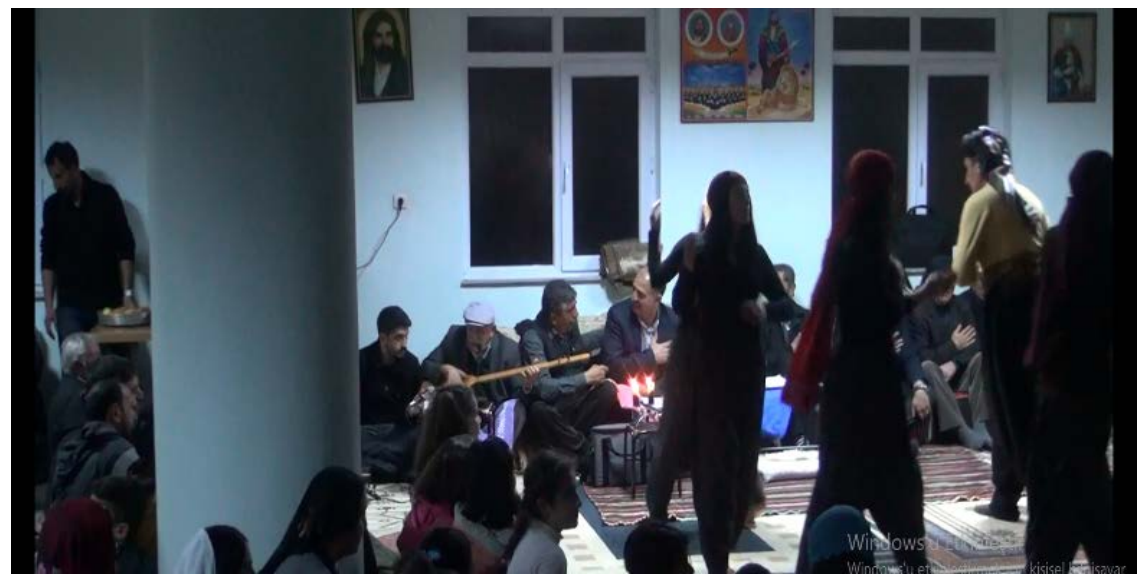

Şekil 2. Tunceli Ovacık İlçesi Hızır Cem'i Görseli (2017).

"Tunceli Cemlerinde Semahların İncelenmesi" adlı master tezinde Yıldız (1992, s.1), Tunceli'de müziğin Cem ibadetlerinin önemli bir parçası olduğunu, bu yüzden Tunceli müziğinin karakteristik özelliklerinin inanç ritüelleri ile yakın ilişki içerisinde olduğunu söylemektedir. Tunceli'nin türkü ve ağıtlarını inceleyen Düzgün ise (1992, s.38), “burada yaşayan Aleviler, dertlerini, duygu ve düşüncelerini türkülerle dile getirdikleri gibi ibadetlerini de deyişler söyleyerek yaparlar. Bu nedenle müzik ve şiir insanların yaşantısinda son derece önemli bir rol oynar. Hem ağlatır, hem de Hak'a yöneltir onları!" diyerek, Tunceli'de müziğin toplumun inanç yapısıyla yakın ilişki içerisinde olduğuna dikkat çekmektedir. Tunceli'de müzik ve bağlamanın inanç değerleri ile olan yakın ilişkisini ortaya koyan önemli kaynaklardan bir diğeri ise, Cumhuriyet dönemi milli musiki-folklor araştırmaları neticesinde 26 Ağustos 1936 'da Tunceli'ye derleme çalışmaları yapmak için ilk seyahatini gerçekleştiren Ferruh Arsunar tarafından 1937 yılında kaleme alınmıştır. Arsunar, Tunceli'nin Pertek ilçesinden başlayarak, Hozat, Pulur ve ZeranikOvacık'ta derleme araştırmaları yaparak derlediği ezgileri Tunceli-Dersim Halk Türküleri ve Pentatonik (1937) adlı bir çalışmada bir araya getirmiştir. Bu araştırmada, Tunceli'deki yerel müziğin Alevi seyitleri (Dedeler, Pirler) tarafından sürdürülüp terennüm edildiği, bu yüzden bölgedeki hakiki müziği "tasavvuf müziğinin" oluşturduğu ifade edilmektedir. Burada Arsunar, tarafından -terminolojik bir dil kullanılarak- ifade edilen tasavvuf musikisi teri- 
minden kast edilenin, Alevi deyişleri-nefesleri olduğu anlaşılmaktadır. Araştırma sürecinde Hozat'ın Karaca köyünde oturan Alevi dedesi, Seyid Seyfi Sarı Saltık ile ilk görüşmesini gerçekleştiren Arsunar, yaptığı görüşmenin Seyfi dedenin bağlama hakkında verdiği bilgilerle başladığını, buralarda çalınan bağlamanın Anadolu'nun birçok yerinde kullanılan şekliyle aynı olduğu söylemektedir. Sonrasında Seyfi Dede'nin bağlamayla Alevilik inancinda önemli bir yere sahip olan Virani, Harabi ve Nesimi gibi halk ozanlarına ait eserleri seslendirdiğini ifade ederek, doğrudan bağlamanın Tunceli'deki inanç değerleri ile olan ilişkisine işaret etmektedir (1937, s.1-2). Arsunar' in ifade ettiği bu halk ozanlarından Virani ve Nesimi Alevi kültüründe "yedi ulu ozanlar" olarak isimlendirilen uluların içerisinde yer almaktadırlar. Ayrıca Harabi'ye ait eserlerin ise, Alevi kültürü-müziği içerisinde önemli bir yere sahip olduğunu söylemek mümkündür. Arsunar, bu araştırmasının önemli bir kısmını bağlamaya ayırarak, bağlamanın kullanım-icra özellikleri hakkında detaylı bilgiler ve görsellere de yer vermektedir (1937, s.7). İkinci görüşmesini ise, Bergani köyünden Seyit Hasan dede ile gerçekleştiren Arsunar, yüz yaşında fakat sağlıklı yapısıyla şaşırtan bilgili birisi olduğunu söylediği Hasan Dede'nin de aynı şekilde Seyfi Dede gibi çaldığı eserleri bağlama ile icra ettiğini söylemektedir. Arsunar'ın yapmış olduğu tespitlerden anlaşılacağ 1 üzere, bağlamanın Alevi dedeleri tarafından icra edilmesi, Tunceli müzik kültürüne yönelik aktarımların Alevi dedeleri tarafından gerçekleştirilmesi veya Virani, Nesimi gibi Alevi ulu ozanlarının eserlerinin seslendirilmesi gibi açıklamalar bağlamanın eski tarihlerden beri Tunceli'deki inanç yapısıyla yakından ilişkili olduğunu ortaya koyan tespitlerdir. Aynı tespit yakın tarihlerde araştırmacı yazar Ali Kaya, tarafından da yapılmıştır. Kaya'ya göre, Tunceli' deki seyitler, dedeler "Pir Sultan, Kaygusuz Abdal, Hatayi, Nesimi, Virani gibi" Alevi halk ozanlarının "deyişlerini çalarlar", semah dönerler ve "türküler söylerler." Ayrıca "Tunceli yöresinde en çok çalınan müzik aleti bağlamadır" (Kaya, 2004, s.120, 143, 280). Bağlama Tunceli inanç sistemi içerisinde önemli bir objedir (Deniz, 2014, s.363). “Bağlama figürü bütün kutsal mekânlarda yer alır (Dalgıç, 2019, s.5). Araştırmada bağlamanın Tunceli'deki toplum-inanç-müzik ilişkisinin önemli bir yansıtıcısı olarak görülmesindeki sebep, bağlamanın geçmişten beri Alevi kültür ve ibadetinin önemli bir parçası haline gelmiş olmasından kaynaklanmaktadır. Alevi toplumlarında bağlamaya bu önemi kazandıran şeyin, Aleviler tarafından ona yüklenen inançsal imgelerle alakalı olduğu söylenebilir. Salcı' ya göre (1940, 
s.9-10), Alevilerin Cem "muhabbetlerinde âşık sazı pek mukaddestir. Onların musiki aletlerinin en makbulü âşık sazıdır." Hatta saz (bağlama) Alevi inanç değerlerinden ötürü o kadar önemli görülmüştür ki, “büyük meydan sazının on iki telli olması on iki imamlara işaret olduğu kanaatini hâsıl etmiş ve bu inanış bütün Alevi kollarının efkârında, erkânında yerleşmiştir." Bağlamaya takılan tel sırası, çalgının göğsüne ve teknesine açılan delikler, bu deliklerin sayısı, sap dibinin gövdeye bitiştiği kısımlarda yer alan şekiller ve sazın bazı parçaları özel remizler olarak bir takım Alevi inançlarını simgeleyen kutsal şeylerdir. Tellerin üç sıra bağlanması, sazın göğsüne ve teknenin üst kısmına açılan üç delik: Allah, Hz. Muhammed, Hz. Ali üçlüsünü temsil etmektedir (Kurt, 2018, s.148). “Eşik Alevilerce kutsaldır. Tekne ilim şehri. Gizli bilimler ve Tanrı'yı bulmaya yarayan hazinedir. Göğüs kapı. Gizli bilimin bozulmasını önleyen yer. Sap elif biçimindedir. Elif Tanrı'ya, Ali'ye değmektir. Fa ve Sol perdesi niyaz, La perdesi Şah perdesi, Mi perdesi ise Hüseyni, Zeynel Abidin, İmam Hüseyin yolu adları verilmektedir" (Kaplan, 2013, s.155). Aleviler için kutsal kabul edilen bu gibi önemli inanç değerlerinin bağlamanın yapısı ile birlikte nesnelleştirilmesinin, Alevi toplumlarında olduğu gibi Tunceli toplumunda da bağlamaya inançsal-kutsal bir anlam yüklediği söylenebilir. Salcı, bağlama ile Alevi inancı arasındaki ilişkiyi, Edirneli Süleyman Rüştü ve Sulhi'nin şu dörtlükleriyle aktarmaktadır.

Et nazar ebrac ve eflak oldu el'an on iki

Gör şuhur vesal ve ay da oldu el'an on iki

Saatın devri bu resm üzerede her an on iki

İkdibas üzere (makamı musikyan) on iki

Bu itibarla sazın kudsiyeti de artyyor ve saz çalmak hakiki ibadet telakkisine mazhar oluyor. Sulhi'de bir nefesinde saz çalmanın ibadet olduğunu söylüyor:

Muhammed Aliden hidayet olur

Haktan bize her dem inayet olur

Saz çalmak Allaha ibadet olur

Davut Peygamberden rebabımız var" (Salc1, 1940, s.10).

Aynı şekilde bağlamanın Alevilik inancı içerisindeki önemine işaret eden ifadelere yedi ulu ozandan birisi olan Pir Sultan Abdal'a ait dörtlüklerde de fazlaca rastlamaktayı. 
“Bugün elime alamaz oldum sazım

Arşa direk direk oldu avazım

Dört şey vardır bir karındaşa lazım

Biri ilim, bir kelam, bir nefes, bir saz"

"Ey benim sarı tamburam

Sen niçin böyle ağlarsın

Derdim büyük, içim oyuk

Ben onun için inlerim

Koluma taktılar teli

Söylettiler bin bir dili

Uydum aynı Cem bülbülü

Ben onun için inlerim" (Kesova, 1975, s.120, 127).

Antalya, Amasya, Tokat gibi bölgelerde yaşayan Alevi toplumlarında bağlamanın dışında farklı çalgılarla karşılaşmak mümkünse de, bağlama Alevi toplumlarının genelinin temel çalgısıdır (Yürükoğlu, 1993, s.60). Cem ritüellerinde zakir tarafından icra edilen bağlama Aleviliğin en temel çalgısı olduğu gibi, "Alevi grup kimliği ve itikatının güçlü bir simgesi" olarak ta kabul edilir (Markoff, 1986, s.48'den akt. Erol, 2018, s.104). Çünkü “bağlamanın Yunus Emre'den beri kullanıldığı yolunda görüşler tam aydınlatılamamışsa da, Sarı Tamburası ile söyleşen Pir Sultan Abdal'dan (16yy) bu yana AleviBektaşi geleneğinin en önemli çalgısı" olmayı sürdürmüştür (Erol, 2015, s.116). Alevi inancı içerisindeki işlevselliğinden ötürü bağlama, geleneksel Alevi kültürünün şekillenmesi ve aktarılmasına aracılık eden temel çalgıdır. Zira Alevi geleneğinde diğer hiçbir çalgı bu kutsiyete sahip değildir; Kuran ile özdeş olmamıştır. Bağlama Cem ritüellerinin içerisinde inancın önemli bir parçası olan Allah, Muhammed, Ali üçlemesiyle birlikte göğüs kısmının öpülmesiyle çalınmaya başlanır ve bitirişler yine aynı şekildedir. Ayrıca "muhabbet sofrasında veya ayin-i cemde saz çalınıp duvaz okunurken herhangi bir şey yenilip içilmez, diz üstü oturulur, konuşulmaz. İcranın Kuran dinleniyorcasına bir saygi ile dinlenmesi gerekir" (Bedri Noyan'dan akt: Kurt, 2016, s.55). Hatta Alevilerin çoğunda bağlamaya "Telli Kuran” denildiği, bağlama ile okunan ezgilerin "nefes, deyiş" veya bu nefeslerin "Hak kelamı" gibi tasavvufi bir söylemle ifade edildiği de bilinmektedir. Dolayısıyla bu inanç 
temelli yaklaşım, Alevi ibadetleri içerisindeki müzikal unsurların sanatsal-estetik kaygıdan ziyade inanç temelli anlam kazanarak sürdürülmesine neden olduğu gibi, bağlamayı Alevi toplumları için kutsal bir emanete dönüştürerek kültürleme yoluyla kuşaktan kuşağa aktarılmasını desteklemiştir. Bu yüzden Türkiye'nin diğer bölgelerinde yaşayan Alevi toplumlarında olduğu gibi, Tunceli toplumu için de bağlama sıradan bir çalgı olmaktan çok, Alevi inanç değerlerinin simgeleştirildiği, inanç felsefesi ve kültürünün aktarıldığı, ibadeti destekleyen "kutsal bir enstrüman olarak karşımıza çıkar" (Dalgıç, 2019, s.25). Buradan hareketle Tunceli' de yaşayan Aleviler için kutsal bir anlamı olan bu çalgı ile okunan deyişler ve türkülerin, Tunceli müziğinin temel kaynağını oluşturduğu, bağlamanın ise bu kaynağı müzikal olarak karakterize ettiği söylenebilir. Dolayısıyla bağlamanın Tunceli'deki geleneksel Alevi müziğinin taşıyıcısı olma misyonu diğer enstrümanlara göre daha yüksektir. Bu özelliğinden ötürü bağlama, Tunceli'de yaşamakta olan Alevilerin müzik kültürlerinin anlaşılması açısından geçmiş ile günümüz arasında nesnel bağlar kuran önemli bir kültürel aktarım aracıdır. Ayrıca bugün özellikle etnomüzikoloji ve müzik sosyolojisinin ilgilendiği konulardan olan kültürleme, kültürleşme, asimilasyon, kültür değişmesi, geleneğin muhafazası gibi süreçlerin, bağlamanın veya herhangi bir başka çalgının toplum içerisindeki yayginlığ1 ve taşıdığı kültürel imgeler -simgeler- üzerinden incelenebileceğini söylemek mümkündür. Çünkü “bir topluluğun bir müziği başkalarına yeğleme eğilimi tarihsel açıdan belli bir müzikal kültürün ve öğrenme döneminin ürünüdür" (Erol, 2015, s.112). Bu yüzden bağlamanın Tunceli'deki günümüz toplumuna aktarım şekli, kültürel belleğin aktarımını destekleyen müzikal yapılar ve kültürel süreçler, eğitim öğretim şeklinin gelenek ve modernlik arasında geçirmiş olduğu değişim ve dönüşüm ilişkileri, geleneğin muhafazası veya geleneğin yeniden icadı gibi kavramlar bağlama özelinde incelenebilir.

\section{Yöntem}

Nicel araştırma desenine sahip bu araştırmada survey araştırma yöntem ve teknikleri kullanılarak elde edilen verilerin istatistiksel analizleri üzerinden durum tespiti ve betimlenmeler yapılmaktadır. Bu araştırmada, genel tarama modellerinin alt basamağını oluşturan tekil tarama modeli kullanılmaktadır. “Değişkenlerin tek tek, tür ya da miktar oluşumlarının belirlenmesi amacı ile 
yapılan araştırma modellerine tekil tarama modelleri denir. Bu tür bir yaklaşımla, ilgilenilen olay, madde, birey, grup, kurum, konu vb. birim ve duruma ait değişkenler ayrı ayrı betimlenmeye çalışılır" (Karasar, 2004, s.79). Tekil tarama modelleri ile zamansal gelişimler ve değişimler belirlenebilmektedir. Zamansal taramalar, izleme ve kesit alma yaklaşımlı taramalar diye ikiye ayrılmaktadır. Bu araştırmada, kesit alma yaklaşımı kullanılmaktadır. Kesit alma yaklaşımlı taramalar, gelişim, çeşitli gelişmişlik evrelerini temsil ettiği kabul edilen gruplar üzerinde yapılacak tarama ve gözlemlerle belirlenmeye çalışıı.ı. Böylece alınan sonuçlar aynı gruptan alınmış gibi yorumlanır ve gelişmenin sürekliliğini yansıttığı varsayılır. Tekil tarama modelli araştırmalarda daha çok betimsel istatistik teknikleri gerekli olur" (Karasar, 2004, s.8081). Bu doğrultuda araştırmanın evreni, Tunceli/Merkez ilçe olarak belirlenmiştir. Araştırmanın verileri tesadüfi örnekleme yöntemi ile yaş ve cinsiyet farklılıkları göz önünde bulundurularak rastgele seçilmiş yüz atmış beş kişiden oluşan katılımcı gruba uygulanan anket formlarından elde edilmiştir. Uygulanan anket formları, sosyolog ve istatistikçi öğretim üyelerinin yanı sıra biri özel bağlama eğitimi veren müzik öğretmeni ve halktan seçilmiş bir kişi ile hazırlanan yirmi altı sorudan oluşmaktadır. Anket soruları, katılımclların demografik özellikleri, Tunceli'de bağlamanın ev ve aile ortamlarındaki yaygınlığı, bağlama çalan kişilerin artan azalan değerleri ve kişilerin bağlama ve inançları arasında kurmuş oldukları ilişkiyi anlamaya yönelik olarak tasarlanmıştır. Anketlerden elde edilen verilerin bilgisayar ortamında SPSS (Social Package for Social Science) programı ile frekans analizleri gerçekleştirilmiştir. Araştırma Munzur Üniversitesi 14.12.2020 E.17278 sayılı etik kurul raporu ile uygun görülmüştür.

\section{Bulgular}

Bu bölümde, katılımcıların demografik özellikleri, Tunceli'de bağlamanın yaygınlığı, insanlar arasındaki kullanım sıklığı ve toplumun inanç yapısıyla olan ilişkisini ortaya koyan istatistiksel dağılımlara yer verilmektedir.

Tablo 1. Katılımcılarn cinsiyet durumuna göre dağılımlan

\begin{tabular}{lll}
\hline Cinsiyet & F & $\%$ \\
\hline Kadın & 67 & 40.6 \\
\hline Erkek & 98 & 59.4 \\
\hline Toplam & 165 & 100 \\
\hline
\end{tabular}


Tablo 1'e bakıldığında katılımcıların cinsiyet değişkenine göre dağılımları \% 59,4 oran ile 98 erkek, \% 40,6 oran ile 67 kadından oluşmaktadır. Bu veriler doğrultusunda anket katılımcıları içerisinde erkek katılımcı oranının kadın katılımcı oranından yüksek olduğu söylenebilir.

Tablo 2. Katılımcıların yaş durumuna göre dağılımları

\begin{tabular}{lll}
\hline Yaş & $\mathbf{F}$ & $\%$ \\
\hline $\mathbf{0 9 - 1 8}$ & 26 & 15,8 \\
\hline $\mathbf{1 9 - 2 8}$ & 26 & 15,8 \\
\hline $\mathbf{2 9 - 3 8}$ & 61 & 37,0 \\
\hline $\mathbf{3 9 - 4 8}$ & 32 & 19,4 \\
\hline $\mathbf{4 9 - 5 8}$ & 13 & 8,0 \\
\hline $\mathbf{5 9 - 6 8}$ & 4 & 2,5 \\
\hline 69 ve üstü yaş & 1 & 0,6 \\
\hline Toplam & 165 & 100 \\
\hline
\end{tabular}

Tablo 2'ye bakıldığında katılımcıların yaş değişkenine göre dağılımları \% 37, 0 F 61 oran ile (29-38) yaş aralığından oluşmaktadır. Devamında ise \% 19, 4 F 32 oran ile (39-48) yaş aralı̆ğ gelirken, \% 0,6 F 1 oran ile (69 ve üstü) değişkenin en düşük orana sahip olduğu görülmektedir. \% 15,8 F 26 oran ile (09-18) ve (19-28) yaş aralıklarının dağılımlarının ise eşittir. Tablo 2' de yer alan verilere bakıldığında, ankete katılanların daha çok orta yaş aralığına sahip bireylerden oluştuğu görülmektedir.

Tablo 3. Katılımcıların eğitim durumuna göre dağılımları

\begin{tabular}{lll}
\hline Eğitim Durumu & $\mathbf{F}$ & $\mathbf{\%}$ \\
\hline Illk-Orta Öğretim & 30 & 18,2 \\
\hline Lise & 49 & 29,7 \\
\hline Üniversite & 75 & 45,5 \\
\hline Yüksek Lisans & 7 & 4,2 \\
\hline Doktora & 3 & 1,8 \\
\hline Toplam & 165 & 100 \\
\hline
\end{tabular}

Tablo 3'e bakıldığında katılımclardan eğitim durumu değişkenine göre dağılımları, \% 45,5 F 75 oran ile üniversite eğitimi, \% 29,7 F 49 oran ile lise eğitiminden oluşmaktadır. Katılımcıların eğitim durumu değişkenine göre dağılımlarının en düşük olduğu oran ise, $\% 1,8 \mathrm{~F} 3$ oran ile doktora eğitimine aittir. Tablo 3'te görüleceği üzere araştırmaya katılan katılımclların sahip oldukları eğitim durumu, büyük oranda üniversite eğitiminden oluşmaktadır. Bu oran lise eğitimi değişkeni ile birlikte ele alındığında, katılımcıların büyük 
bir kısmının eğitimli bireylerden oluştuğunu söylemek mümkün hale gelir. Tablo 3'de yer alan verilerin, aynı zamanda ankete katılan bireylerin, Tunceli toplumu ve kültürü içerisindeki sosyal statüleri hakkında fikirler verdiği de söylenebilir. Çünkü sosyolojik olarak bireyin sahip olduğu eğitim durumu, onun aynı zamanda toplum ve kültür içerisindeki konumu-statüsü üzerinde de etkili bir faktördür. Bu yüzden ankete katılan kişilerin toplumsal statülerinin anlaşılması için sorgulanan eğitim durumu değişkeninin, hem Tunceli'deki müzik ve toplum ilişkisinin anlaşılması hem de araştırmanın müzik sosyolojisiyle olan bağlantılarını güçlendirmek adına önemli olacağı söylenebilir. Çünkü sosyolojik olarak bireyin toplum içerisindeki konumunu belirleyen demografik ve sosyal statü gibi özellikler, müziğin toplum içerisindeki konumu ve sahip olduğu toplumsal özellikleri açıklamaya yardımcı olan sosyolojik veriler arasında yer almaktadır. Tablo 2 ve Tablo 3'de yer alan, yaş aralığı ve eğitim durumu oranları birlikte değerlendirildiğinde, ankete kattlan bireylerin Tunceli'deki dahil oldukları toplumsal kesim ve statünün, 2948 yaş aralığına sahip eğitimli bireylerinden oluştuğu söylenebilir.

Tablo 4. Katılımcıların medeni durumlarına göre dağılımlar

\begin{tabular}{lll}
\hline Medeni Durum & F & \% \\
\hline Evli & 79 & 47,9 \\
Bekâr & 84 & 50,9 \\
\hline Toplam & 165 & 100 \\
\hline
\end{tabular}

Tablo 4'de katılımcların medeni durumlarına göre oranları \% 50,9 F 84 bekâr, \% 47,9 F 79 evli olarak dağılmaktadır. Dolayısıyla ankete katılan bekâr katılımcı oranının evli katılımcı oranından yüksek olduğu söylenebilir.

Tablo 5. Katılımcılarnn meslek durumlarna göre dağılımlarn

\begin{tabular}{lll}
\hline Meslek & F & \% \\
\hline Öğrenci & 34 & 26,6 \\
\hline Öğretmen & 7 & 4,2 \\
\hline Akademisyen & 4 & 2,4 \\
\hline Memur-İşci & 83 & 50,3 \\
\hline Esnaf & 11 & 6,7 \\
\hline Emekli & 7 & 4,2 \\
\hline Hiçbiri & 19 & 11,5 \\
\hline Toplam & 165 & 100 \\
\hline
\end{tabular}


Tablo 5'e bakıldığında katılımcıların meslek değişkenine göre dağılımlarının, \% 50,3 F 83 oranı ile memur-işçi değişkeninde yoğunlaştığı görülmektedir. Öğrenci değişkeni \% 34 F 26,6 oranına sahipken, \% 2,4 F 4 oranı ile akademisyen değişkenin ise düşük bir orana sahiptir. Tablo 5 'te ankete kattlan katılımcılardan hiçbir mesleğe sahip olmayan (çalışmayan) kişiler için kullanılan hiçbiri değişkeni ise \% 11,5 F 19 oranına sahiptir. Tablo 5'te öğrenci değişkeni dışında yer alan diğer değişkenler bir araya getirildiğinde, katılımclların büyük oranda meslek sahibi-çalışan bireylerden oluştuğu görülmektedir. Tablo 3'te toplumsal statü bağlamında eğitim durumu değişkeni üzerinden açıklamaya çalıştı̆̆ımız faktörlerin, aynı şekilde bireyin toplumsal statüsünün belirlenmesinde önemli bir role sahip olan meslek değişkeni içinde geçerli olduğu söylenebilir. Meslek kavramı bireyin toplumsal statüsünü belirleyen en önemli kavramlardan biri olduğu gibi aynı zamanda Tunceli' deki müzik ve toplum ilişkisini toplumsal statü bağlamında açıklamaya yarayan bir diğer değişkendir.

Tablo 6. Katılımcıların doğum yeri durumlarına göre dağılımları

\begin{tabular}{lll}
\hline Doğum Yeri & $\mathbf{F}$ & $\mathbf{\%}$ \\
\hline Merkez & 102 & 61,8 \\
\hline Hozat & 8 & 4,8 \\
\hline Ovacık & 6 & 3,6 \\
\hline Mazgirt & 17 & 10,3 \\
\hline Nazmiye & 8 & 4,8 \\
\hline Pertek & 8 & 4,8 \\
\hline Pülümür & 3 & 1,8 \\
\hline Çemişgezek & 4 & 2,4 \\
\hline Toplam & 165 & 100 \\
\hline
\end{tabular}

Tablo 6'da görüleceği üzere araştırmanın örneklemi olarak seçtiğimiz Merkez ilçe değişkeni, \% 61,8 F 102 oran ile katılımcıların doğum yerlerinin en yüksek orana sahip olduğu değişkeni oluşturmaktadır. \% 1,8 F 3 ile Pülümür ilçesinin, katılımcıların doğum yeri dağılımlarına göre en düşük orana sahip olan değişken olduğu görülmektedir. Katilımcıların toplumsal özelliklerini tespit etmeyi amaçladığımız doğum yeri dağılımları üzerinden, Tunceli'deki müzik ve toplum ilişkisinin ilçelere göre nasıl özellikler gösterdiği sosyolojik ilişkiler kurularak yorumlanabilir. Dahası katılımcıların doğum yeri değişkenlerinin aktarıldığı Tablo 6 ile araştırmanın ilerleyen kısımla- 
rında yer verdiğimiz bağlamanın Tunceli' deki yaygınlık ve kullanım oranlarını yansıtan tablolar arasında ilişkiler kurularak, bağlamanın Tunceli' de sahip olduğu toplumsallığı geleneğin muhafazası veya geleneğin yok olması gibi kültürel süreçler bağlamında değerlendirilebilmek mümkündür.

Tablo 7. Katılımcıların yaşadıkları mahalle durumlarına göre dağılımları

\begin{tabular}{lll}
\hline Mahalle & $\mathbf{F}$ & $\mathbf{\%}$ \\
\hline Atatürk & 84 & 50,6 \\
\hline Cumhuriyet & 33 & 19,9 \\
\hline Moğultay & 17 & 10,2 \\
\hline Ali baba & 14 & 8,4 \\
\hline İsmet İnönü & 4 & 2,4 \\
\hline Aktuluk & 2 & 1,2 \\
\hline Esentepe & 4 & 2,4 \\
\hline Yeni mahalle & 4 & 2,4 \\
\hline Toplam & 165 & 100 \\
\hline
\end{tabular}

Tablo 7'ye bakıldığında katılımcıların mahalle değişkenine göre dağılımlarının \% 50,6 F 84 oran ile Atatürk mahallesinde yoğunlaştı̆̆ı görülmektedir. Katılımcların mahalle değişkenine göre dağılımlarının en düşük olduğu değişkenin ise, \% 1,2 F 2 oran ile Aktuluk Mahallesi olduğu söylenebilir.

Tablo 8. Katılımcıların mensup olduklarn aşiretlere göre dağılımlar

\begin{tabular}{lll}
\hline Aşiret & $\mathbf{F}$ & $\mathbf{\%}$ \\
\hline Kureşan & 30 & 18,2 \\
\hline Alan & 23 & 13,9 \\
\hline Yusufhan & 16 & 9,7 \\
\hline Demenan & 8 & 4,8 \\
\hline Sarn Saltuk & 4 & 2,4 \\
\hline Pilvenk & 13 & 7,9 \\
\hline Baba Mansur & 4 & 2,4 \\
\hline Derviş Cemal & 6 & 3,6 \\
\hline Huran & 5 & 3,0 \\
\hline Haydaran & 2 & 1,2 \\
\hline Toplam & 165 & 100 \\
\hline
\end{tabular}

Tunceli aşiretler bakımından zengin bir coğrafyaya sahiptir. Tablo 8'de yer alan değişkenler, Tunceli'de yer alan en büyük aşiretler içerisinden seçilerek oluşturulmuştur. Katılımcların aşiret değişkeni üzerinden dağılımlarına baktığımızda, \% 18,2 F 30 oran ile Kureşan aşiretinin en yüksek orana 
sahip olduğu görülmektedir. \% 13,9 F 23 oran ile Alan aşireti katılımcı dağ1lımlarının en yüksek olduğu ikinci aşirettir. Katılımcıların aşiret değişkenine göre dağılımlarını \% 9,7 F 16 oranı ile Yusufhan aşireti, \% 7,9 F 13 oranı ile Pilvenk aşireti oluşturmaktadır. Dağılımlarının en düşük olduğu değişken ise \% 1,2 F 2 ile Haydaran aşiretidir. Tunceli'de yaşayan insanlar tarafından dini ritüellerin çoğu Ocak-Merkezli olarak uygulanmaktadır. “Tunceli Alevilerinde Ocak yaygın olarak kullanılan bir kavramdır. Bir soy ağacıyla başlayan, toplumsal konum siralamasıyla devam eden, çeşitli görevleri düzenleyen, Alevi adap ve erkanın kurumsallaşmasını şekillendiren" töreleri yaşatmak için toplumsal zemin hazırlayan Ocak kavramı Tunceli'de yaşayan Alevi toplulukları için önemlidir (Yıldırım, 2013, s.876). Tablo 8'de diğer aşiret değişkenlerine göre daha yüksek bir orana sahip olan Kureşan aşireti, Tunceli'nin en yoğun ve en kalabalık Ocak'larından birisidir. Kureşan aşiretinin soy şeceresi On İki İmamlardan birisi olan İmam Musa-i Kâzım'dan başlar ve şuan Tunceli' de türbesi bulunan Seyit Hacı Kureyiş'e kadar dayanır (Wakamatsu, 2013, s.962-963). Sahip olduğu şecere bakımından Kureşan aşiretin dedeleri veya pirleri Tunceli inanç sistemi içerisinde önemli bir yere sahiptir. Örneğin Tunceli toplumu için önemli inanç öğeleri ve merkezlerinden birisi olan Düzgün Baba, Kureşan ocağına bağlı bir evliyadır. Hatta Düzgün Baba Tunceli toplumunun inanç yapısında o kadar önemli bir yere sahiptir ki, insanların çoğu yemin ederlerken bile Düzgün Baba'nın ismini zikrederek yemin ederler. Dolayısıyla Kureşan Ocağının Tunceli inanç yapısı içerisinde önemli bir role sahip olduğu söylenebilir.

Tablo 9. Katılımcıların evlerinde bağlama bulundurma düzeylerine göre dağılımlarn

\begin{tabular}{lll}
\hline Evinizde Bağlama Var mı? & F & $\%$ \\
\hline Evet & 121 & 73,3 \\
\hline Hayır & 43 & 26,1 \\
\hline Toplam & 165 & 100 \\
\hline
\end{tabular}

Tablo 9'da araştırmanın odak noktalarından birisini oluş̧uran bağlamanın Tunceli toplumdaki yaygınlık düzeyi, öncelikle katılımcıların evlerinde bağlama bulundurma oranları üzerinden aktarılmaktadır. Tablo 9'a baktığ1mızda katılımcların \% 73, 3 F 121 oranında evlerinde bağlama bulundurdukları görülmektedir. Buradan hareketle bağlamanın Alevi toplumlar içerisindeki yaygınlığının, Tunceli'de de aynı şekilde olduğu görülmektedir. 
Tablo 10. Katılımcıların evlerinde bulundurduklan bağlamanın tür özelliklerine göre dağılımlan

\begin{tabular}{lll}
\hline Bağlama Türü & $\mathbf{F}$ & $\mathbf{\%}$ \\
\hline Kopuz-Cura & 2 & 1,2 \\
\hline Dede Bağlama & 6 & 3,6 \\
\hline Kisa Saplı Bağlama & 89 & 53,9 \\
\hline Uzun Saplı Bağlama & 24 & 14,5 \\
\hline Toplam & 121 & 73,2 \\
\hline
\end{tabular}

Tablo 10'da günümüzde Tunceli toplumunda yaygın olan bağlama türünün, \% 53,9 F 89 oranı ile kısa bağlama olduğu görülmektedir. Buna karşılık Alevi dedeleri, pirleri ile özdeşleşmiş olan ve inanç geleneğinin imgesel olarak en önemli taşıyıcısı kabul edilen Dede bağlama \% 3,6 F 6 oranına sahipken, Kopuz-Cura \% 1,2 F 2 oranına sahiptir. Türklerin en eski çalgılarından birisi olan kopuz, geçmişte daha çok şaman ayinlerinde, ayini yöneten kam, baksı, ozan gibi kişiler tarafından kullanılan bir çalgıdır. "Kopuzun isim değiştirmeden Alevi inancına mensup bazı topluluklar arasında yaşatıldığı, Cem ritüelinin kutsal çalgısı olarak" icra edilmektedir (Akın, 2020, s.145). Hatta günümüzde Alevilik inancını kültürel antropoloji perspektifiyle inceleyen araştırmalarda, kopuz ile bağlama arasında ilişki, Alevilik ile Şaman kültürü arasındaki ilişkinin önemli bir göstergesi olarak kabul edilir (Ocak, 2003; Yazıc1, 2014). Tunceli'de kopuzun, daha çok geçmişte Alevi dedeleri tarafından kullanıldığı bilinmektedir. Yaklaşık olarak on yıldır Tunceli'de yaşadığımız süreçte, özellikle dede soyundan gelen, babası Alevi dedesi olan ailelerin evlerinde yaklaşı yüz yıl öncesine ait olduğu belirtilen kopuz türleriyle karşılaşılmıştır.

Bu doğrultuda Tablo 10'da yer alan değişkenler birbirleri ile kıyasland1ğında, geçmişte daha çok Alevi dedeleri tarafından kullanılan dede bağlama veya Kopuz-Curanın düşük oranlara sahip olduğu, günümüz Tunceli'sinde kısa bağlamanın daha yaygın olduğu görülmektedir. Kısa bağlamanın teknik ve yapısal özellikleri bakımından günümüzde halk müziği içerisinde yaygın olarak kullanılması ve yaşanan modernizasyon süreçlerinin bu durum üzerinde etkisinin olduğu söylenebilir. Fakat her ne kadar kullanılan bağlama yapısal özellikleri itibariyle farklılıklar gösterse de, genel itibari ile inancın bir parçası olan bağlama figürünün -gerek kopuz-cura, gerekse kısa veya uzun bağlamanın- Tunceli toplum yapısı içerisinde \% 73, 3 F 121 oranı ile yerini 
koruduğu ve yaygın olan bağlama türünün ise, \% 53,9 F 89 oranı ile kısa bağlama olduğu görülmektedir.

Tablo 11. Katılımcılarn evlerinde bulundurdukları bağlama sayısına göre dağılımları

\begin{tabular}{lll}
\hline Evinizdeki Bağlama Sayısı & $\mathbf{F}$ & $\mathbf{\%}$ \\
\hline $\mathbf{1}$ & 80 & 48,5 \\
\hline $\mathbf{2}$ & 24 & 14,5 \\
\hline $\mathbf{3}$ & 12 & 7,3 \\
\hline $\mathbf{4}$ & 3 & 1,8 \\
\hline $\mathbf{5}$ & 2 & 1,2 \\
\hline Toplam & 121 & 73,3 \\
\hline
\end{tabular}

Katılımcıların evlerindeki bağlama sayısına ait değişkenleri Tablo 11'den incelediğimizde, \% 48,5 F 80 oranı ile 1 değişkeni en yüksek orana sahipken, \% 1,2 F 2 oranı ile 5 değişkeninin düşük bir orana sahip olduğu görülmektedir. Fakat tüm değişkenler bir araya getirildiğinde katılımcıların evlerinde toplamda 121 tane bağlama olduğu anlaşılmaktadır. Bu oran Tablo 9'da yer alan verilerle de tutarlılık göstermektedir.

Tablo 12. Katılımcıların evlerinde bağlamadan başka bir çalgı bulundurma durumlarına göre dağılımlan

\begin{tabular}{lll}
\hline Evinizde Bağlamadan Başka Bir Çalgı Var mı? & F & \% \\
\hline Evet & 72 & 43,6 \\
\hline Hayır & 79 & 47,9 \\
\hline Toplam & 151 & 91,5 \\
\hline
\end{tabular}

Tablo 12' de katılımcıların evlerinde \% 47,9 F 79 oranıyla bağlama dışında başka bir çalgı bulunmazken \% 43,6 F 72 oranı ile evlerinde başka bir çalgı bulunmaktadır. Her iki değişkene bakıldığında aralarında önemli bir fark görülmemektedir. Dolayısıyla bu değişken ve tablo 9, 10 ve 11 'de yer alan değişkenler üzerinden Tunceli'de toplumun müziğe önem verdiği ve herhangi bir müzik aleti çalmaya ilgili olduklarını söylemek mümkündür.

Tablo 13. Katılımcılarn evlerinde bağlamadan başka bulundurdukları çalgıların tür özelliklerine göre dă̆ılımları

\begin{tabular}{lll}
\hline Evinizdeki Bağlama Dışındaki Çalgı Türü & $\mathbf{F}$ & $\mathbf{\%}$ \\
\hline Gitar & 31 & 18,8 \\
\hline Keman & 5 & 3,0 \\
\hline Piyano & 14 & 8,5 \\
\hline Yan Flüt & 7 & 4,2 \\
\hline Erbâne & 4 & 2,4 \\
\hline Diğer & 16 & 9,7 \\
\hline Toplam & 77 & 46,7 \\
\hline
\end{tabular}


Tablo 13'de katılımcıların evlerinde bağlamadan başka bulundurdukları çalgının türü, \% 18,8 F 31 oranında gitar iken, onu \% 9, 7 F 16 ile diğer seçeneği \% 8,5 F 14'le piyano izlemektedir. Tablo 13'de yer alan veriler ile yukarıda aktardığımız bağlamanın toplumdaki yaygınlık düzeyini ortaya koyan Tablo 9 ve Tablo 11'de yer alan veriler karşılaştırıldığında, Tunceli'de bağlamanın diğer esntrümanlara göre daha yaygın olduğu anlaşılmaktadır. Dolayısıyla bağlamanın yaygınlık derecesi ile diğer enstrümanlar kıyaslandığında, günümüz Tunceli'sinde inancın bir paçası olan bağlamanın geleneksel olarak muhafazasının sürdürüldügünü söylemek mümkündür. Bunun yanı sıra Tablo 13'e bakıldığında, katılımcıların evlerinde bulundurdukları çalgı türleri arasında, piyano, yan flüt ve keman gibi Klasik Batı müziğine ait çalgıların da var olduğu görülmektedir.

Tablo 14. Katılımcların bağlama çalma düzeylerine göre dağılımlan

\begin{tabular}{lll}
\hline Bağlama Çalmayı Biliyor musunuz? & F & \% \\
\hline Az Biliyorum & 46 & 27,9 \\
\hline Orta Seviyede Biliyorum & 33 & 20,0 \\
\hline İyi Biliyorum & 8 & 4,8 \\
\hline Çok İyi Biliyorum & 4 & 2,4 \\
\hline Bilmiyorum & 67 & 40,6 \\
\hline Toplam & 158 & 95,8 \\
\hline
\end{tabular}

Tablo 14'de görüldüğg̈ üzere bağlama çalmayı biliyor musunuz? sorusuna cevap veren 158 katılımcıdan toplamda 91 tanesinin bağlamayı belirli seviyelerde çalabildiği anlaşılmaktadır. Örneğin \% 27,9 F 46 oranında katılımcı bağlama çalmasını az bilirken, \% 20,0 F 33 orta seviyede, \% 4,8 F 8 iyi seviyede bağlama çalmasını bilmektedir. Tablo $14^{\prime}$ de yer alan istatiksel dağılımlar üzerinden Tunceli'de bağlama çalabilen kişi sayısı ile Tunceli'de bağlamanın yaygınlık oranları arasında anlamlı bir bağ kurulabilmek mümkündür. \% 73, 3 F 121 oranında evlerinde bağlama bulunduran katılımclardan toplamda 91'i aynı zamanda belirli seviyelerde bağlama çalmasını bilmektedirler.

Bağlamanın Tunceli'de yaşayan Alevilerin inanç ritüellerinin vazgeçilmez bir parçası olması, aynı zamanda insanların bağlamaya karşı ilgi göstermelerine, çalabilmelerine ve bu eylem üzerinden müzikal beceri kazanabilmelerine yardımcı olan kültürel bir müzik eğitimi formasyonunun gerçekleşmesine katkı sağlamaktadır. Çünkü inanç ritüelleri içerisinde yer alan birey, ritüelin gerçekleşmesinde aktif olarak kullanılan bağlama ile hem görsel hem 
de işitsel olarak temas kurmaktadır. Bunun dışında sosyal çevresi içerisinde (ev ve aile ortamlarında) bireylerin bağlama ile olan muhataplığı da bu durumu desteklemektedir. Dolayısıyla bu durum bireyin müzikal olarak kültürlenmesine aracılık eden bir özellik-işlevsellik kazanmaktadır. İnancın gereği olarak bireyin kültür alanı içerisinde, görsel ve işitsel olarak bağlama ve müzikal unsurlarla sürekli temas içerisinde olması, onun bağlamaya ve müziğe yönelik olarak bilgi ve beceriler kazanmasına yardımcı olan dolaylı bir müzik eğitimi formasyonu sağlamaktadır. Yani inanç öğeleriyle örülmüş olan kültür ortamı bireyin müzik terbiyesini yönlendirmekte ve bu doğrultuda müzikal beceriler kazanmasına aracılık etmektedir. Bu yüzden inanç ritüelleri ve sosyal çevre içerisinde yer alan bağlama ve müzikal unsurlar, kültürleme aracılığıyla dolaylı olarak bireye aktarılmakta ve böylelikle bireyin müzik eğitimine katkı sağlamaktadır. Dolayısıyla Alevilik inancının, bağlamanın Tunceli' deki yaygınlık oranları ve bireylerin bağlama yönelik müzikal beceriler kazanmasında etkin bir rol sahibi olduğu söylenebilir.

Tablo 15. Katılımcılarnn çaldıkları bağlamanın tür özelliklerine göre dağılımlan

\begin{tabular}{lll}
\hline Hangi Bağlamayı Çalmayı Biliyorsunuz? & $\mathbf{F}$ & $\mathbf{\%}$ \\
\hline Kopuz-Cura & 0 & 0 \\
\hline Dede Bağlama & 4 & 2,4 \\
\hline Kısa Saplı Bağlama & 63 & 38,2 \\
\hline Uzun Saplı Bağlama & 18 & 10,9 \\
\hline Hepsi & 3 & 1,8 \\
\hline Toplam & 88 & 53,3 \\
\hline
\end{tabular}

İnanç sembolizmi olarak bir manaya sahip olan bağlamanın günümüz Tunceli'sinde hangi türünün yaygın olarak kullanıldığına Tablo 15'de baktğımızda ise \% 38,2 F 63 ile insanlar tarafından en çok çalınan bağlamanın Kısa Saplı Bağlama olduğu görülmektedir. Tablo 10'da katılımcıların evlerinde yaygın olarak bulundurdukları bağlama türünün Kısa Saplı Bağlama olduğu tespit edilmiştir. Tablo 10 ve tablo 15'de yer alan verilere göre Kısa Saplı Bağlamanın Tunceli'de yaşayan insanlar arasında hem bulundurma hem de çalma oranlarıyla ön planda olduğunu göstermektedir. Dolayısıyla ev ortamlarında yaygın olarak bulundurulan Kısa Saplı Bağlamanın çalınma oranlariyla tutarlı bir ilişkiye sahiptir. Buradan hareketle kültürel olarak toplum içerisinde yaygın olarak bulundurulan bağlama türünün insanların çaldıkları bağlama türünü de etkilediği söylenebilir. Ayrıca bulundurulan bağlama türü ve insanların çaldıkları bağlama türü gibi değişkenlerin sahip oldukları 
oranlar üzerinden Tunceli'deki müzik ve toplum ilişkisinde bağlamanın önemli bir yere sahip olduğu daha da netlik kazanmaktadır. Kısa Bağlamanın akort ve perde yapısı itibari ile icra açısından Dede Bağlama veya KopuzCura'ya göre sağladığı kolaylıktan ötürü, günümüzdeki Alevi toplumlarında Kısa Bağlamanın daha yaygın olarak kullanıldığı bilinmektedir. Dede Bağlama veya Kopuz perde yapısı itibariyle genellikle dokuz veya on iki perde aralığına sahiptir. Ayrıca akort sistemi olarak bu bağlamalar La kararında 1. tel: Re, 2. tel: La, 3. tel: Do olarak akort edilmektedir. Dolayisiyla bu perde ve akort sistemi ile günümüzde zengin bir yapıda olan halk müziği ve Alevi müziğine ait her türlü eseri makamsal olarak icra etmek Kısa Bağlamaya göre daha zordur. Kısa Bağlama ise genel olarak on dokuz perdelidir ve günümüzde Türk müziğinin en son şekli olan yirmi dört aralıklı perde yapısıyla birlikte düşünüldüğünde eserlerin makamsal olarak icrası Dede Bağlamaya göre daha uyumlu ve kolaydır. Akort sistemi ise, La karar 1. tel: Re, 2. tel: Sol, 3. tel: La şeklinde akort edilmektedir. Sahip olduğu perde ve akort sistemi açısından Kısa Saplı Bağlama icra açısından Dede Bağlama veya Kopuz'a göre daha kolaylık sağlamaktadır. Bu yüzden eskiye nazaran günümüzde Kısa Bağlama sağladığı icra kolaylığı sebebiyle halk müziği ve Alevi müziği içerisinde daha yaygın kullanılmaya başlanmıştır. Dolayısıyla Tunceli toplumu içerisinde aktarılan ve işlevsellik kazanan bağlama türünün Kısa Bağlama olarak gerçekleşmesinde bu durumun önemli bir etkisi olduğunu söylemek mümkündür.

Tablo 16. Katılımcıların bağlama çalma sürelerine göre dă̆ılımları

\begin{tabular}{lll}
\hline Yaklaşık Olarak Kaç Yıldır Bağlama Çalıyorsunuz? & $\mathbf{F}$ & $\mathbf{\%}$ \\
\hline $\mathbf{0 - 5}$ & 50 & 30,3 \\
\hline $\mathbf{6 - 1 0}$ & 14 & 8,5 \\
\hline $\mathbf{1 1 - 1 5}$ & 12 & 7,3 \\
\hline $\mathbf{1 6 - 2 0}$ & 7 & 4,2 \\
\hline $\mathbf{2 1 - 2 5}$ & 3 & 1,8 \\
\hline $\mathbf{2 6 - 3 0}$ & 3 & 1,8 \\
\hline Toplam & 89 & 53,9 \\
\hline
\end{tabular}

Tablo 16'dan katılımcıların \% 30, 3 F 50'si yaklaşık olarak 0-5 yıldan beri bağlama çalar iken toplamda 89 kişinin en az 0-5 yıldan başlamak kaydıyla belirli zaman aralıklarında bağlama çalmayı bildikleri görülmektedir. Tablo 
16' da yer verdiğimiz değişkenler katılımcıların bağlama çalmayı ne kadar süredir gerçekleştirdiklerinin tespiti ile ilgilidir. Tablo 16 'da katılımcıların toplamda 25 tanesinin bağlamayı 10 ila 30 yıl arasında çaldıkları görülmektedir.

Tablo 17. Katılımcıların bağlama çalmasını öğrenme durumlarına göre dağılımları

\begin{tabular}{lll}
\hline Bağlama Çalmasını Nasıl Öğrendiniz? & $\mathbf{F}$ & $\mathbf{\%}$ \\
\hline Kendi Kendime & 34 & 20,6 \\
\hline Anne-Baba & 4 & 2,4 \\
\hline Abi-Abla & 1 & 0,6 \\
\hline Dede-Nine & 0 & 0 \\
\hline Arkadaş & 7 & 4,2 \\
\hline Özel Kurs Merkezi & 47 & 28,5 \\
\hline Toplam & 93 & 56,4 \\
\hline
\end{tabular}

Tablo 17 'ye bakıldığında katılımcıların bağlama çalmasını $\%$ 28,5 F 47 oranında özel kurs merkezlerinde öğrendikleri anlaşılmaktadır. Bu veriler, Tunceli'de bağlama eğitimine yönelik formel aktarım biçiminin, geleneksel aktarıma göre daha ön planda olduğunu gösterir. Fakat \% 20,6 F 34 oranında katılımcının bağlama çalmasını geleneksel olarak kendi kendilerine öğrenmeleri geleneksel aktarımın Tunceli' de hala etkisinin devam ettiğinin önemli işaretlerinden birisidir. Ayrıca Tablo 17'de yer alan aile bireyleri gibi değişkenlerin, Tunceli'de bağlamanın kültürel olarak aktarımına etkisinin düşük olduğu görülmektedir. Fakat aile bireylerine ait veriler Kendi Kendime değişkeni ile bir arada ele alındığında, Tunceli'de kültürlemenin bağlamının aktarımın sürecinde etkisini sürdürmeye devam ettiği daha da netlik kazanmaktadir.

Tablo 18. Katılımcıların bağlamayla tanıştıkları durumlarına göre dağılımları

\begin{tabular}{lll}
\hline Bağlamayla Nasıl Tanıştınız? & $\mathbf{F}$ & $\mathbf{\%}$ \\
\hline Aile Ortamında & 81 & 49,1 \\
\hline İş Ortamında & 1 & 0,6 \\
\hline Arkadaş Ortamında & 25 & 15,2 \\
\hline Okul Ortamında & 3 & 1,8 \\
\hline Cem İbadeti Vasıtasıyla & 7 & 4,2 \\
\hline Toplam & 117 & 70,9 \\
\hline
\end{tabular}

Katılımcların Tablo 18'de bağlamayla nasıl tanıştıkları sorusuna verdikleri cevaplar, Tunceli'de bağlamanın aktarım ve kültürel süreçleri hakkında bilgi verdiğinden önemli görülmektedir. Yukarıda aktarılan Tablo 9'da yer alan katılımcıların evlerinde bağlama bulundurma düzeyleri ile Tablo 17' de katılımcıların bağlama çalmasını kendi kendilerine öğrenmeleri ve Tablo 
18'de katılımcıların bağlamayla tanışma ortamları arasında yakın ilişkiler kurmak mümkündür. \% 73, 3 F 121 oranında evlerinde bağlama bulunduran katılımcıdan 81'i bağlamayla aile ortamında tanışmış, bunlardan \% 20,6 F 34 'ü ise bağlama çalmasını kendi kendilerine öğrenmişlerdir. Bütün bu verilere bakıldığında Tunceli toplumu içerisinde bağlamanın ev ortamlarında bulundurma düzeyleri bireylerin bağlamayı kendi kendilerine öğrenme ve bağlamayla tanışma oranlarını etkilediği söylenebilir. Ayrıca Tablo 18 ' de yer alan ikinci yüksek değişken \% 15,2 F 25 oranıyla arkadaş ortamı değişkeni iken, \% 4,2 F 7 Cem ibadetleri vasıtasıyla değişkeninin düşük bir orana sahip olduğu görülmektedir. Bütün bu veriler bir araya getirildiğinde Tunceli'de bağlamanın aktarımında aile, arkadaş gibi sosyal çevrenin önemli bir rolü olduğu görülmektedir. Fakat katılımcıların bağlamayla tanışmalarında toplumun inanç ritüellerinden olan Cem ibadetlerinin rolü ise diğer değişkenlere göre daha azdır.

Tablo 19. Katılımcıların bağlamayla icra ettikleri müzik türü durumlarna göre dağılımlan

\begin{tabular}{l|l|l}
\hline Bağlama ile en çok hangi müzik türünü çalarsınız? & F & $\mathbf{\%}$ \\
\hline Deyişler-Nefesler & 29 & 17,6 \\
\hline Halk Müziği & 61 & 37,0 \\
\hline Sanat Müziği & 2 & 1,2 \\
\hline Özgün-Arabesk Müzik & 2 & 1,2 \\
\hline Etnik-Kurmanci Müzik & 5 & 3,0 \\
\hline Toplam & 99 & 60,0 \\
\hline
\end{tabular}

Katılımcllar bağlama ile en çok hangi müzik türünü çalıyorsunuz sorusuna \% 54,6 F 90 oranında Halk Müziği cevabını vermişlerdir. Deyişler-Nefesler değişkeni ise \%17,6 F 29 oranına sahiptir. \% 1,2 F 2 oranı ile Sanat müziği ve Özgün-Arabesk müzik türleri düşük oranlara sahip olan değişkenlerdir. Görüleceği üzere geleneksel Alevi müziğine ait Deyişler-Nefesler, bağlamayla icra açısından Halk müziği değişkeninden sonra gelmektedir. Fakat popüler kültür ürünü olan arabesk-özgün müzik türlerinin bağlamayla icrası bu türlere göre daha düşüktür. Dolayısıyla Tunceli'de geleneksel olan müzik türlerinin muhafazası ve sürekliliğinin toplum içerisinde sağlandığını söylemek mümkündür. 
Tablo 20. Katılımcıların ailelerinde bağlama çalmasını bilen kişi durumlarına göre dağılimlar

\begin{tabular}{l|l|l}
\hline Ailenizde bağlama çalan birisi var mı? & F & $\%$ \\
\hline Anne-Baba & 39 & 23,6 \\
\hline Abi-Abla & 20 & 12,1 \\
\hline Dede-Nine & 3 & 1,8 \\
\hline Kardeş & 20 & 12,1 \\
\hline Çocuk & 15 & 9,1 \\
\hline Toplam & 97 & 58,8 \\
\hline
\end{tabular}

Tablo 20'ye bakıldığında katılımcıların ailelerinde \% 23,6 F 39 oranında Anne-Babaları bağlama çalmasını bilirken, \% 12,1 F 20 oranı ile Abi-Abla, Kardeş değişkenlerinin aynı oranlara sahip olduğu görülmektedir. Yukarıda yer verdiğimiz Tablo 17'de yer alan katılımcıların bağlama çalmasını nasıl öğrendiniz değişkeni ile Tablo 20'de yer alan veriler karşılaştırıldığında, katılımcıların Anne-Babaları \% 23,6 F 39 oranında bağlama çalmasını bilmelerine rağmen, katılımcıların bağlama çalmasını öğrenme oranlarına etkisinin \% 2,4 F 4'le düşük bir orana sahip olduğu görülmektedir. Bu durum aynı şekilde Abi-Abla değişkeni içinde söz konusudur. Tablo 17 'de \% 0, 6 F 1 oranına sahip olan Abi-Abla değişkeni Tablo 20'de \% 12,1 F 20'dir. Her iki tabloda yer alan veriler göstermektedir ki, katılımcıların aile bireyleri bağlama çalmasını bilirlerken, katılımcıların bağlama çalmasını öğrenme ve aktarım süreçlerine etkisi oldukça düşüktür. Günümüzde modernleşme, popüler kültür gibi sosyolojik değişimlerin etkisiyle bağlamanın aktarımı geleneksel olarak aile içerisinde değil daha çok özel kurs merkezleri tarafından sürdürmektedirler. Bunların dışında Tablo 14'e dönülecek olursa 165 katılımcının 91'i bağlama çalmasını bilirken, aynı zamanda bu katılımcıların toplam aile bireylerinin 97'si de bağlama çalmasını bilmektedir. Bu durum dolaylı olarak Tunceli'de bağlamanın toplum arasında çalınma oranlarının fazlalığına işaret etmektedir. Her iki tabloda yer alan bağlama çalmasını bilen katılımcı ve aile bireyleri değişkenleri bir arada ele alındığında toplam 188 kişinin bağlama çalmasını bildiği anlaşılmaktadır. Bu oranlar Tunceli'de bağlamanın yaygınlığı ve kullanım oranları adına önemli bir göstergedir. Ayrıca Tablo 20'de dikkat çeken diğer bir ayrıntı ise, aile bireylerinden Dede-Nine, Anne-Baba veya Abi-Abla gibi önceki kuşak bireylerin bağlama çalmasını bilmeleri, Tunceli'de bağlamanın kuşaklar arasında sürekliliğinin sağlandığının önemli bir işaretidir. Fakat bu bireylerin bağlama çalmasını bilmelerine rağmen aile içerisinde bağ- 
lamanın aktarımı ve sürekliliğinde rol sahibi olmadıkları görülmektedir. Örneğin katılımcıların Dede-Nine, Anne-Baba veya Abi-Abla'ları bağlama çalmasını bilmelerine rağmen katılımcılar bağlama çalmasını geleneksel olarak kendi kendilerine öğrenmişlerdir.

Tablo 21. Katılımcılarn bağlama ile Alevilik inancı arasında kurduklarn ilişki durumlarına göre dağılımları

\begin{tabular}{lll}
\hline Bağlamayla Aleviliği İlişkili Buluyor musunuz? & F & $\mathbf{\%}$ \\
\hline Az Buluyorum & 6 & 3,6 \\
\hline Kısmen Buluyorum & 35 & 21,2 \\
\hline Çok Buluyorum & 112 & 67,9 \\
\hline Bulmuyorum & 7 & 4,2 \\
\hline Hiç Bulmuyorum & 0 & 0 \\
\hline Toplam & 160 & 97,0 \\
\hline
\end{tabular}

Anket verilerinin bilgisayar ortamına girişleri yapıldığında bağlama çalmasını bilen bilmeyen veya evinde bağlama olup olmayan herkesin bu ve devamında yer alan sorulara cevap verdiği gözlemlenmiştir. Tablo 21'e bakıldığında Tunceli'deki Alevi kültürü ile bağlamayı ilişkili buluyor musunuz? sorusuna katılımcıların \% 65,5 F 108'i çok ilişkili buldukları cevabını vermişlerdir. Hiç ilişki bulmayanların oranı ise dikkat çekici bir şekilde F $0 \%$ 0 'dır. Araştırmada önemle üzerinde durduğumuz konulardan biri olan Tunceli'deki Alevi inanç yapısının toplumda bağlamanın yaygınlığına, insanların bağlama çalabilmesine, müzik öğrenebilme ve yapabilme becerilerine ne gibi bir katkısı vardır sorusuna aradığımız cevap, katılımcıların Tablo. 21'de Alevilik ve bağlama ilişkisine verdikleri cevaplar ile netlik kazanmaktadır. Tablo 21 'de yer alan verilerden anlaşılacağı üzere bağlamanın Tunceli toplumun inanç değerleri ile yakından ilişkili olduğu ve Aleviliğin Tunceli'de bağlamayı toplum algısında önemli bir yere koymaktadır. Bu durum bağlamanın Tunceli'deki yaygınlığına veya insanların bağlamaya olan ilgilerini önemli ölçüde etki ettiği söylenebilir.

Tablo 22. Katılımcılarnn Tunceli'deki Alevi kültürü ile bağlama arasında kurduklarn ilişki durumlarnna göre dă̆ılımlan

\begin{tabular}{lll}
\hline Tunceli'deki Alevi kültürü ile bağlamayı ilişkili buluyor musunuz? & F & $\mathbf{\%}$ \\
\hline Az Buluyorum & 10 & 6,1 \\
\hline Kısmen Buluyorum & 32 & 19,4 \\
\hline Çok Buluyorum & 108 & 65,5 \\
\hline Bulmuyorum & 6 & 3,6 \\
\hline Hiç Bulmuyorum & 0 & 0 \\
\hline Toplam & 156 & 94,5 \\
\hline
\end{tabular}


Tablo 22'de yer alan verilere bakıldığında \% 65,5 F 108 oranı ile çok buluyorum değişkeni yüksek bir orana sahipken, Tunceli'deki Alevi kültürü ile bağlama arasında ilişki bulmayan katılımcıların oranı ise 0 'dır. Tablo 21 ve Tablo 22'de yer alan veriler birlikte düşünüldügünde Tunceli toplumunun inanç yapısı ile bağlama arasındaki ilişkinin yüksek oranlara sahip olduğu söylenebilir. Tablo 22'de görüleceği üzere, ankete katılan 165 kişiden 108'i Tunceli'deki Alevi kültürü ile bağlamayı çok ilişkili bulurken, bunlardan 32'si kısmen, 10'tanesi de az ilişkili bulmaktadır. Dolayısıyla Tunceli'deki inanç yapısıyla bağlama arasında yakın bir ilişki olduğunu, inancın bağlamanın toplum içerisindeki konumu üzerinde oldukça etkili bir faktör olduğunu söylemek mümkündür.

Tablo 23. Katılımcılarn inanç değerleri açısından bağlama ile kurdukları anlamsal bütünlüğe yönelik dağılımları

\begin{tabular}{lll}
\hline Bağlama sizce ne düzeyde kutsal bir çalgıdır? & F & $\mathbf{\%}$ \\
\hline Hiç & 31 & 18,8 \\
\hline $\mathbf{A z}$ & 10 & 6,1 \\
\hline Kısmen & 35 & 21,2 \\
\hline Çok & 45 & 27,3 \\
\hline Oldukça çok & 33 & 20,0 \\
\hline Toplam & 154 & 93,3 \\
\hline
\end{tabular}

Tablo 23'e bakıldığında katılımcllar, bağlama \% 27,3 F 45 oranıyla "çok" kutsal bir çalgı olarak görürken, \% 21,2 F 35 oranıla "kısmen" F 33 \% 20,0 oranına sahip katılımcı ise bağlamayı "oldukça çok" kutsal bir çalgı olarak görmektedirler. Yukarıda aktarılan Tablo 21 ve 22 'de yer alan verilerle Tablo 23'de yer alan veriler karşılaştırıldığında bağlamanın Tunceli'deki toplum algısında Alevilik inançla yakından ilişkili olduğu söylenebilir. Tablo 23'de yer alan veriler göstermektedir ki, bağlama Tunceli'de sıradan bir çalg1 olmaktan ziyade kutsal bir manaya sahiptir.

Tablo 24. Katılımcılarn bağlamaya "Telli Kuran" denilmesine katılma durumlarnna göre dağılımlan

\begin{tabular}{lll}
\hline Bağlamaya Telli Kuran denilmesine katılıyor musunuz? & F & $\mathbf{\%}$ \\
\hline Kesinlikle katılıorum & 21 & 12,7 \\
\hline Katılıyorum & 58 & 35,2 \\
\hline Katılmiyorum & 48 & 29,1 \\
\hline Kesinlikle katılmıyorum & 13 & 7,9 \\
\hline Toplam & 140 & 84,8 \\
\hline
\end{tabular}


Tablo 24'de görüleceği üzere katılımcılar \% 35,2 F 58 oranı ile bağlamanın Telli Kuran olarak ifade edilmesine katılıyorum cevabını verdikleri görülmektedir. \% 29,1 F 48 oranı ile katılmıyorum cevabı ikinci yüksek orana sahipken, \% 7,9 F 13 oranına sahip katılımcı ise bağlamanın Telli Kuran olarak ifade edilmesi görüşüne katılmamaktadır. Dolayısıyla Tablo 24'de yer alan veriler bağlamanın Tunceli'de inançla olan ilişkisini desteklemektedir.

Tablo 25. Katılımcılara göre bağlamanın ifade ettiği kavram durumlarına göre dağılımlar

\begin{tabular}{lll}
\hline Sizce Bağlama aşağıdaki kavramlardan hangisini ifade etmektedir? & $\mathbf{F}$ & $\mathbf{\%}$ \\
\hline Halk müziğini & 74 & 44,8 \\
\hline Aleviliği & 70 & 42,4 \\
\hline Herhangi bir müzik aletini & 11 & 6,7 \\
\hline Eğlence aracını & 2 & 1,2 \\
\hline Hiçbiri & 2 & 1,2 \\
\hline Toplam & 159 & 96,4 \\
\hline
\end{tabular}

Tablo 25'de görüleceği üzere katılımcılar için bağlama \% 44,8 F 74 oranı ile halk müziği kavramını ifade ederken, sonrasında ise $\% 42,8 \mathrm{~F} 70$ oranı ile Alevilik kavramını ifade etmektedir. Her iki kavram arasında ciddi bir fark bulunmadığı söylenebilir. Bu oranlar dışında \% 1,2 F 2 oranı ile Eğlence Aracı ve Hiçbiri değişkenlerinin düşük oranlara sahip oldukları görülmektedir. Anket yapılan katılımcılardan toplamda 70 kişinin bağlamayı Alevilik kavramıyla özdeşleştirmesi, Tunceli'de bağlamanın Alevi inancı ile olan ilişkisini ortaya koyan diğer bir değişken olduğu söylenebilir.

Tablo 26. Katılımcıların dinleme tercihi durumlarna göre dağılımlan

\begin{tabular}{lll}
\hline Daha çok hangi tür müzik dinlemeyi tercih edersiniz? & $\mathbf{N}$ & $\mathbf{\%}$ \\
\hline Halk Müziği & 133 & 80,6 \\
\hline Türk Sanat Müziği & 3 & 1,8 \\
\hline Klasik Batı Müziği & 8 & 4,8 \\
\hline Rock-Jazz-Hiphop vd. & 18 & 11,1 \\
\hline Toplam & 162 & 98,2 \\
\hline
\end{tabular}

Tablo 26'da \% 80, 6 F 133 oranı ile Halk Müziği değişkeninin en yüksek orana sahip olduğu görülmektedir. \% 11,1 F 18 oranı ile Rock-Jazz-Hiphop vd. değişkeni ikinci yüksek orana sahipken, Klasik Batı Müziği değişkenin oranı ise, $\%$ 4, 8 F 8 ' dir. Tablo 26 'da yer alan veriler yukarıda aktarılan Tablo 19 'daki verilerle karşılaştırıldığında katılımcıların bağlama ile en çok icra ettikleri müzik türü ile dinlemeyi tercih ettikleri müzik türü arasında yakın bir ilişki olduğunu söylemek mümkündür. Örneğin katılımcılar \% 37,0 F 61 
oranı ile bağlamayla en çok halk müziği icra ederlerken, \% 80, 6 F 133 gibi yüksek bir oranda halk müziği dinledikleri görülmektedir.

Tablo 22'den başlayarak Tablo 26'ya kadar olan soru grubuyla katılımc1ların Alevilik inanç ve kültürü ile bağlama arasında nasıl bir ilişki kurdukları anlaşılmaya çalışılmıştır. Araştırmamızın odak noktasını oluşturan bu ilişkiyi ortaya koymaya çalıştı̆̆ımız bu sorulara katılımcılar tarafından verilen cevaplar, Tunceli'de bağlama ile Alevilik inancı arasında yakın bir ilişki olduğunu göstermektedir. İnsanlar bağlamaya sıradan bir müzik aleti olmaktan çok, onu kendi inanç değerleri içerisinde bir yere konumlandırmakta, bağlamaya inançsal bir mana yüklemektedirler.

\section{Sonuç}

$\mathrm{Bu}$ araştırmanın sonucunda elde ettiğimiz verilerden de anlaşlacağı üzere, Tunceli' de yaşayan insanlar arasında bağlama çalgısının yaygın olarak kullanıldığı, katılımcıların birçoğunun evlerinde bağlama bulundurdukları, bağlama çalmasını belirli seviyelerde bildikleri, ailelerinde bağlama çalmasını bilen kişilerin azımsanmayacak kadar var olduğu ve bağlama ile inançları arasında yakın ilişkiler kurdukları gözlemlenmiştir. Anket uygulanan 165 katılımcının evlerinde 121 adet bağlama olması, bu kişilerden toplamda 91'inin ve aile bireylerinden toplamda 97'sinin bağlama çalmasını bilmeleri Tunceli'de bağlamanın yaygın olarak kullanımının önemli göstergelerindendir.

Günümüz Tunceli'sinde toplum arasında yaygın olarak kullanılan bağlama türü, \% 53,9 F 89 oranı ile kısa bağlamadır. Geçmişte daha çok Alevi dedeleri-pirleri ile özdeşleşmiş olan, günümüzde ise modernleşme ve popüler kültür paradigmalarının etkisiyle Alevi müziği içerisinde giderek popülerleşmeye başladığını gözlemlediğimiz Dede bağlama \% 3, 6 F 6, KopuzCura bağlamanın ise \% 1,2 F 2 oranları ile Tunceli'de yaygın olmadığı görülmektedir. Fakat bağlamanın Alevi inancı içerisinde sahip olduğu imgesel konum ve ibadetin gerçekleştirilmesindeki aracı rolü göz önünde bulundurulduğunda, Tunceli'de bağlamanın toplum ve inanç içerisindeki yerini muhafaza ettiği görülmektedir. Bunun en önemli göstergeleri olarak, katılımcıların bağlama ile Alevilik inancı, Tunceli'deki Alevilik kültürü, bağlamanın kutsallğı veya Telli Kuran olarak ifade edilmesiyle ilgili görüşlerinin sorgulandığ 1 Tablo 21, 22, 23, 24 ve 25' de yer alan istatistiksel dağılımlar gösterilebilir. Katılımcıların \% 67,9 F 112'sinin Alevilik inancı ile bağlamanın "oldukça çok" 
ilişki olduğunu düşünmesi veya Tunceli' deki Alevilik inancı ile bağlama arasındaki ilişkiyi \% 65,5 F 108 oranında "çok" ilişkili bulmalanı, Tunceli'de bağlamanın yaygınlığının toplumun inanç yapısıyla yakından ilişkili olduğunu ortaya koyan verilerden bazılarıdır. Ayrıca katılımcıların bağlamayı sıradan bir çalgıdan ziyade \% 27, 3 F 45 oranında "çok", \% 20,0 F 33 oranında "oldukça çok" kutsal bir çalgı olarak görmeleri, bağlamaya Telli Kuran denilmesine \% 35, 2 F 58 oranında "kat1lyyorum", \% 12, 2 F 21 oranında "kesinlikle katılıyorum" cevabını vermeleri veya bağlamanın katılımcılar için \% 42, $4 \mathrm{~F}$ 70 oranında Aleviliği temsil etmesi gibi istatistiksel sonuçlar, Tunceli'de bağlamanın inançla yakından ilişkili olduğunu ortaya koyan diğer veriler arasında gösterilebilir. Buradan hareketle bağlamanın Alevilik inanç yapısıyla özdeşleşmiş olmasının, Tunceli' de bağlamanın diğer çalgılara göre yaygınlığını desteklediği gibi inanç içerisindeki konumunu da muhafaza ettiği görülmektedir.

Bireylerin ev, aile, arkadaş ortamı gibi sosyal çevrelerinde bağlamanın yaygın olarak yer alması, Tunceli toplumunun bağlamaya olan ilişkisini artırmaktadır. Bu yaygınlığın dolaylı olarak insanların bağlamaya karşı ilgilerini arttırdığı, çalabilme ve işitsel olarak müzikal beceriler kazanmasına yardımcı olan geleneksel bir ortam hazırlayarak katkı sağladığı söylenebilir. Toplumun sahip olduğu Alevi inanç yapısı ve beraberinde oluşan sosyal çevre, bireyin dolaylı yollarla müzikal olarak kültürlemektedir. Bu durumu ortaya koyan en önemli göstergeler \% 49,1 F 81 oranında katılımcının bağlama ile aile ortamında, \% 15, 2 F 25 oranında arkadaş çevrelerinde tanışmalarıdır. Bunun yanı sıra katılımcıların \% 20,6 F 34 oranında bağlama çalmasını "kendi kendilerine" öğrenmeleri de bu görüşümüzü desteklemektedir. Fakat Cem ibadetlerinin bağlamanın toplum içerisindeki kültürel aktarımdaki rolü oldukça düşüktür. Ayrıca 165 katılımcının aile bireylerinden toplamda 97'si bağlama çalmasını bilmektedir. Aile bireylerinden Dede-Nine, Anne-Baba veya Abi-Abla gibi önceki kuşak bireylerin bağlama çalmasını bilmeleri, Tunceli'de bağlamanın kuşaklar arasında sürekliliğinin sağlandığının önemli bir işaretidir. Fakat bu bireylerin bağlama çalmasını bilmelerine rağmen aile içerisinde bağlamanın aktarımı ve sürekliliğinde rol sahibi olmadıkları görülmektedir. Örneğin katılımcıların Dede-Nine, Anne-Baba veya Abi-Abla'ları bağlama çalmasını bilmelerine rağmen katılımcılar bağlamayı yüksek oranda özel kurs merkezleri veya kendi kendilerine öğrenmişlerdir. 
Tunceli'de bağlamadan sonra toplum arasında yaygın olan çalgı türünün, \% 18,8 F 31 oranı ile "gitar" olduğu söylenebilir. Bunun yanı sıra Tablo 13'te yer alan 14 piyano, 7 yan flüt, 5 keman gibi değişkenler, Tunceli'de bağlamadan sonra Klasik Batı Müziğgi'ne ait çalgıların yaygın olarak kullanıldığını göstermektedir. Ayrıca anket yapılan 165 katılımcının evlerinde toplamda 121 tane bağlama, bağlamadan başka ise toplamda 72 farklı çalgı türü bulunmaktadır. Bu verilerden hareketle Tunceli toplumunun müzikle yakından ilişkili olduğunu söylemek mümkündür.

Özetle söylemek gerekirse günümüz Tunceli'sinde bağlama hala sıradan bir müzik aleti olmaktan çok Alevilik inancıyla yakından ilişkili olan ve toplum içerisindeki yaygınlığı muhafaza edilen bir çalgıdır. Bunun dışında bağlamanın yaygın kullanımı, bağlama çalan kişilerin fazlalığı, bağlamadan başka çalgı türlerinin toplum arasındaki yaygınlığı gibi değişkenler ise, Tunceli toplumunun müzikle yakından ilişkili olduğunu göstermektedir. 
EXTENDED ABSTRACT

\section{Music and Society Relationship in the Context A Study of Music Sociology: In Tunceli Prevalence of Baglama and Its Relation to the Belief Structure of the Society}

Tuncay Yildirim

Munzur University

The perspective of this research is to do music sociology in the context of the relationship between music and society. Placing a musical work in its social context, thus dressing its overall portrait with a particular garment is the only way to understand that work. It can be said constitutes the starting point of music sociology this simple reductionist approach, which facilitates the concretization of the relationship between music and society. Basically the sociology of music is a discipline that aims to understand the relationship between music and human beings, tries to establish a unity of meaning between the social and music. To embody the abstract pure structure formed by sounds of music and are made reductions social continual to explain its differences, and musical differences between people, masses or societies, is explained by being reduced to the social context in which is produced of music. When considered from these angles, this research the general perspective and points of focus, mainly because it creates a relationship between music and society, the research itself is possible to evaluate under the title of music sociology directly. Because what is tried to be understend with this research, is relationship a how between the belief structure of the society wiht the prevalence of baglama in Tunceli. The Baglama is one of the indispensable elements of Alevism belief. Therefore, reflections of the relationship between music and society in Tunceli, is handle from over the baglama instrument which is one of the most important elements of Alevi belief rituals. The Alevism belief effect on its position bağlama's in Tunceli society, for people meanings it carries and the musical equipment earned to society through acculturation that belief, The Baglama, which is no longer an ordinary musical instrument with 
its place in the Alevi belief system, is discussed over the widespread usage rates in Tunceli society.

Tunceli has hosted many civilizations in the past due to its region and location, is a city where have been carried to the present day traces of many civilizations such as Sumer, Hittite, Assyrian Urartu, Med, Byzantine, Seljuk and Ottoman. Tunceli, is ranks last when compared to other citys in the country in terms of population and population density. Tunceli, which has a rich heritage in terms of cultural features, is a place where live densely people have Alevi belief identity. Ninety percent of the people are Alevis. The Cem rituals which are the worship of Alevis living in Tunceli realization by music and baglama, the bağlama while putting tying in an important place in people's lives, the bağlama's is contributes significantly to the formation of cultural processes that ensure the continuity of cultural transfer. Hizır Cem, Twelve Muharrem Cem, Görgü Cem, Musahiplik Cem, Kırklar Cem, etc. in all Cem rituals that have different purposes and practices, music and context is an intricate structure intertwined with belief.

This research was carried out by using survey research methods and techniques in quantitative research designs. The universe of the research has been determined as Tunceli / Central district. The sample group of the research, is consists from one hunder sixty five people selected randomly by random sampling method taking into account age and gender differences. The data were obtained from the questionnaire forms applied to the participant group. Applied survey forms, sociologist and statistician faculty members, is consists of twenty six questions prepared with a private baglama teacher and a person selected from the public. Survey questions, was designed to understand the demographic characteristics of the participants, the prevalence of baglama in home and family environments in Tunceli, the increasing and decreasing values of those who play the baglama, and the relationship that people have established between baglama and beliefs. Data obtained from surveys, were carried out frequency analyzes using the SPSS (Social Package for Social Science) program in computer environment.

Some of the tables of the findings of the study are as follows: 
Table 9. The participants, distribution of according level of bindings the bağlama at home

\begin{tabular}{lll}
\hline Do You Have Binding in Your Home? & F & $\%$ \\
\hline Yes & 121 & 73,3 \\
\hline No & 43 & 26,1 \\
\hline Total & 165 & 100 \\
\hline
\end{tabular}

Table 10. The participants distribution of according type characteristics of the bağlama bindings at home

\begin{tabular}{lll}
\hline The Bağlama Type & $\mathrm{F}$ & $\%$ \\
\hline Kopuz-Cura & 2 & 1,2 \\
\hline Grandpapa Baglama & 6 & 3,6 \\
\hline Short Handle of Bağlama & 89 & 53,9 \\
\hline Long Handle of Bağlama & 24 & 14,5 \\
\hline Total & 121 & 73,2 \\
\hline
\end{tabular}

Table 11. The participants distribution of according number of the bağlama bindings at home

\begin{tabular}{lll}
\hline Number of The Bağlama in Your Home & F & $\%$ \\
\hline 1 & 80 & 48,5 \\
\hline 2 & 24 & 14,5 \\
\hline 3 & 12 & 7,3 \\
\hline 4 & 3 & 1,8 \\
\hline 5 & 2 & 1,2 \\
\hline Total & 121 & 73,3 \\
\hline
\end{tabular}

Table 14. The participants distribution of according level playing of the bağlama

\begin{tabular}{lll}
\hline Do you know play baglama & $\mathrm{F}$ & $\%$ \\
\hline I know little & 46 & 27,9 \\
\hline I know at level middle & 33 & 20,0 \\
\hline I know well & 8 & 4,8 \\
\hline I know very well & 4 & 2,4 \\
\hline I do not know & 67 & 40,6 \\
\hline Total & 158 & 95,8 \\
\hline
\end{tabular}

Table 15. The participants distribution of according characteristics type of the baglama they play

\begin{tabular}{lll}
\hline Do You Know Playing of Wihich The Bağlama? & F & $\%$ \\
\hline Kopuz-Cura & 0 & 0 \\
\hline Grandpapa Baglama & 4 & 2,4 \\
\hline Short Handle of Bağlama & 63 & 38,2 \\
\hline Short Handle of Bağlama & 18 & 10,9 \\
\hline All & 3 & 1,8 \\
\hline Total & 88 & 53,3 \\
\hline
\end{tabular}


Table 18. The participants distribution of according they meet with baglama re dă̆ılımları

\begin{tabular}{lll}
\hline How Did You Meet With Baglama? & $\mathrm{F}$ & $\%$ \\
\hline In Family Environment & 81 & 49,1 \\
\hline In Business Environment & 1 & 0,6 \\
\hline In Friendship & 25 & 15,2 \\
\hline In School Environment & 3 & 1,8 \\
\hline Through Cem Worship & 7 & 4,2 \\
\hline Total & 117 & 70,9 \\
\hline
\end{tabular}

Table 22. The participants distribution of according relationship they establish between the Alevi culture in Tunceli with Baglama

\begin{tabular}{lll}
\hline Do you find related Baglama with the Alevi culture in Tunceli? & F & $\%$ \\
\hline I Find Less & 10 & 6,1 \\
\hline Partially I Find & 32 & 19,4 \\
\hline I find Very & 108 & 65,5 \\
\hline I don't Find & 6 & 3,6 \\
\hline I Never Find & 0 & 0 \\
\hline Total & 156 & 94,5 \\
\hline
\end{tabular}

As can be seen from the data we have obtained as a result of this research, is widely used the baglama among people living in Tunceli, most of the participants had Baglama in their homes, they know at certain levels playing the bağlama, has been very under will not be underestimated who know how to play baglama in their families, and they are establish close relationships between their beliefs with the baglama. To be found 121 of the Bağlama at home of 165 participants who were surveyed, 91 of these people in total and 97 of their family members know how to play the bağlama, is one of the important indicators of use widespread of the bağlama's in Tunceli.

To put it in a nutshell, in today's Tunceli, Baglama still is not an ordinary musical instrument, is an instrument that is closely related to the Alevi belief and whose prevalence is preserved in the society.

\section{Kaynakça / References}

Akın, B. (2020). Kopuz'dan Telli Kuran'a Türklerde sazın kültürel serüveni ve kutsallığı. Türk Dünyası İncelemeleri Dergisi, 20(1), 135-162.

Arsunar, F. (1937). Tunceli Dersim Halk Türküleri Ve Pentatonik. İstanbul: Resimli Ay Matbaasi.

Ayas, G. (2015). Müzik Sosyolojisi: Sorunlar-yaklaşımlar-tartışmalar. İstanbul: Doğu Kitapevi. 
Dalgıç, P. (2019). Alevi inancında deyişler: Tunceli örneği. Yayımlanmış Yüksek Lisans Tezi, Munzur Üniversitesi Sosyal Bilimler Enstitüsü, Sosyoloji Anabilim Dal, Tunceli.

Demir, N. (2019). Ailelerin bakış açısı ile tunceli ilindeki öğrencilerin teog başarıların etkileyen faktörler. Yayımlanmış Yüksek Lisans Tezi, Furat Üniversitesi Eğitim Bilimleri Enstitüsü / Eğitim Bilimleri Anabilim Dalı, Elazığ.

Deniz, D. (2012). Yol/Re: Dersim inanç sembolizmi; antropolojik bir yaklaşım. İstanbul: İletişim Yayıncllık.

Düzgün, M. (1992). Dersim türküleri (ă̆ıtlar): Tayê lawıkê Dêrsımi. Ankara: Berhem Yayınları.

Erol, A. (2015). Müzik üzerine düşünmek. Ankara: Bağlam Yayıncılık.

Erol, A. (2018). İslam, alevilik ve müzik. İstanbul: Bağlam Yayıncilık.

Finkelstein, S. (1995). Besteci ve ulus (müzikte halk mirası). İstanbul: Pencere Yayınları.

Gültekin, A. K. (2007). Tunceli'de sünni olmak: Ulusal ve yerel kimliköğelerinin Tunceli-Pertek'te Etnolojik Tetkiki. Yayımlanmış Yüksek Lisans Tezi, Ankara Üniversitesi Sosyal Bilimler Enstitüsü Halk Bilim Ana Bilim Dalı, Ankara.

Günay, E. (2011). Müzik sosyolojisi, sosyolojiden müzik kültürüne bir bakış. Ankara: Bağlam Yayıncilik.

Güven, U. Z., ve Ergur, A. (2014). Dünyada ve Türkiye'de müzik sosyolojisinin yeri ve gelişimi. Sosyoloji Dergisi, 29(2), 1-19.

Kaplan, A. (2013). Kültürel müzikoloji. İstanbul: Bağlam Yayıncllı.

Karasar, N. (2004). Bilimsel araştırma yöntemi. Ankara: Nobel Yayın Dağıtım.

Kaya, A. (2004). Tunceli (Dersim) kültürü. İstanbul: Can Yayınları.

Kurt, N. (2016). Alevi-Bektaşi cemlerinde deste bağlama geleneği ve "bağlama" adının kaynağı. Ë̈ Devlet Türk Musikisi Konservatuarı Dergisi, 8, 43-62.

Kurt, N. (2018). Alevilik Erkânında Zakir ve Bağlama. IV. Uluslararası Alevilik ve Bektaşilik Sempozyumu Bildiri Kitabı, 18-20 Ekim, Ankara.

McGregor, C. (1983). Pop kültür oluyor. (çev. G. Özferendeci), İstanbul: Çiviyazıları.

Ocak, A. Y. (2003). Alevi ve Bektaşi İnançlarımın İslam öncesi temelleri. İstanbul: İletişim Yayınları.

Ozankaya, Ö. (1982). Toplumbilimine giriş. Ankara: S Yayınları.

Parlayan, D. (2012). Tunceli ve çevresinde halk inanışları. Yayımlanmış Yüksek Lisans Tezi, Frrat Üniversitesi, Sosyal Bilimler Enstitüsü, Felsefe ve Din Bilimleri Anabilim Dalı, Elazığ. 
Salc1, V. (1940). Gizli Türk halk musikisi ve Türk Musikisinde armoni meseleleri. İstanbul: Numune Matbaası.

Shiner, L. (2001). Sanatın icadl: Bir kültür tarihi, (çev. İ. Türkmen), İstanbul: Ayrınt1 Yayınları.

Solak, A. (Ed). (2016). Tunceli İli sosyal analiz çalışması. Ankara: Hegem Yayınları.

Soykan, Ö. N. (2005). Sanat sosyolojisi: Kuram ve uygulama., İstanbul: Dönence Yayınları.

Stokes, M. (1992). Türkiye'de arabesk olayı, (çev. H. Eryılmaz), İstanbul: İletişim Yayinları.

Şener, C. (2002). Alevilerin etnik kimlï̆i: Aleviler Türk mü Kürt Mü?. İstanbul: Etik Yayınları.

Turan S., Kantar, H. (2012). Tunceli halk müziği: Semah, deyiş, nefes, türkü, oyun havası. Ankara: Tunceli Valiliği.

Wakamatsu, H. (2013). Dersim'de küreselleşen ocak-aşiret ilişkileri: Dini ritüeller ve evliya inancı hakkında antropolojik bir yaklaşım. 2. Uluslararası Dersim Sempozyumu, Eylül 2013, Tunceli.

Yazıcı, M. (2014). Alevilik-Alevi deyişlerinin ve gülbanglarının sosyolojik analizi. İstanbul: Çıra Yayınları.

Yürükoğlu, R. (1993). Değirmenin bendine: Arif Să̆'la müzik, alevilik ve siyaset üzerine sohbet. İstanbul: Alev Yayınları.

Yıldız, S. (1992). Tunceli Cemleri'nde Semahların İncelenmesi. Yayımlanmış Yüksek Lisans Tezi, İstanbul Teknik Üniversitesi, Sosyal Bilimler Enstitüsü, İstanbul.

Yıldırım, E. (2013). Alevi ocaklarının günümüzdeki sosyal fonksiyonları. 2. Uluslararası Dersim Sempozyumu, Eylül 2013, Tunceli.

\section{Kaynakça Bilgisi / Citation Information}

Yıldırım, T. (2021). Müzik sosyolojisi bağlamında Tunceli'de bağlama çalgısının yaygınlığı ve toplumun inanç yapısıyla olan ilişkisi. OPUS-Uluslararası Toplum Araştırmaları Dergisi, 17(36), 2675-2713. DOI: 10.26466/opus.841307 